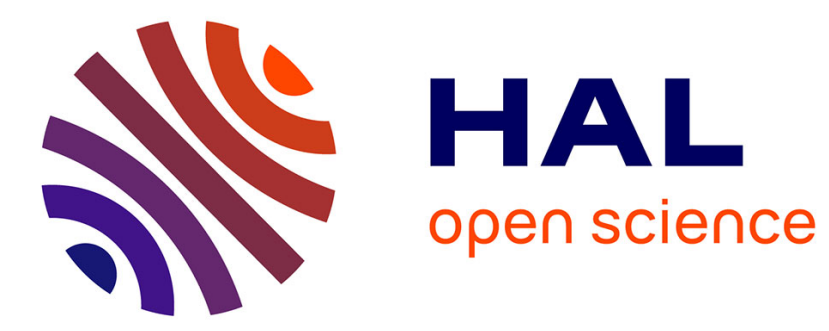

\title{
CD95/Fas and metastatic disease: What does not kill you makes you stronger
}

Jean Philippe Guégan, Christophe Ginestier, Emmanuelle Charafe-Jauffret, Thomas Ducret, Jean-François Quignard, Pierre Vacher, Patrick Legembre

\section{- To cite this version:}

Jean Philippe Guégan, Christophe Ginestier, Emmanuelle Charafe-Jauffret, Thomas Ducret, JeanFrançois Quignard, et al.. CD95/Fas and metastatic disease: What does not kill you makes you stronger. Seminars in Cancer Biology, 2020, 60, pp.121-131. 10.1016/j.semcancer.2019.06.004 . hal02179928

\section{HAL Id: hal-02179928 \\ https://hal-univ-rennes1.archives-ouvertes.fr/hal-02179928}

Submitted on 12 Sep 2019

HAL is a multi-disciplinary open access archive for the deposit and dissemination of scientific research documents, whether they are published or not. The documents may come from teaching and research institutions in France or abroad, or from public or private research centers.
L'archive ouverte pluridisciplinaire HAL, est destinée au dépôt et à la diffusion de documents scientifiques de niveau recherche, publiés ou non, émanant des établissements d'enseignement et de recherche français ou étrangers, des laboratoires publics ou privés. 


\section{Seminars in Cancer Biology}

CD95/Fas and metastatic disease: What does not kill you makes you stronger

Authors: Jean Philippe Guégan ${ }^{1,2}$, Christophe Ginestier ${ }^{3}$, Emmanuelle Charafe-Jauffret ${ }^{3}$, Thomas Ducret ${ }^{4,6}$, Jean-François Quignard ${ }^{4,6}$, Pierre Vacher ${ }^{4,5,7}$, and Patrick Legembre ${ }^{1,2,7, *}$

\section{Affiliations:}

${ }^{1}$ CLCC Eugène Marquis, Équipe Ligue Contre Le Cancer, Rennes, France

${ }^{2}$ Université Rennes, INSERM U1242, Rennes, France

${ }^{3}$ Aix-Marseille Univ, Inserm, CNRS, Institut Paoli-Calmettes, CRCM, Epithelial Stem Cells and Cancer Lab, Marseille, France

${ }^{4}$ Université de Bordeaux, Bordeaux, France

${ }^{5}$ INSERM U1218, Bordeaux, France

${ }^{6}$ Centre de Recherche Cardio Thoracique de Bordeaux, INSERM U1045, Bordeaux, France ${ }^{7}$ Shared last-authorship

*Corresponding author: Patrick Legembre, Centre Eugène Marquis, Rue Bataille Flandres Dunkerque, 35042 Rennes, France. Telephone: (+33)-223237241; E-mail: patrick.legembre@inserm.fr 


\begin{abstract}
CD95 (also known as Fas) is the prototype of death receptors; however, evidence suggests that this receptor mainly implements non-apoptotic signaling pathways such as NF- $\kappa \mathrm{B}, \mathrm{MAPK}$, and PI3K that are involved in cell migration, differentiation, survival, and cytokine secretion. At least two different forms of CD95L exist. The multi-aggregated transmembrane ligand (mCD95L) is cleaved by metalloproteases to release a homotrimeric soluble ligand (s-CD95L). Unlike m-CD95L, the interaction between s-CD95L and its receptor CD95 fails to trigger apoptosis, but instead promotes calcium-dependent cell migration, which contributes to the accumulation of inflammatory Th17 cells in damaged organs of lupus patients and favors cancer cell invasiveness. Novel inhibitors targeting the pro-inflammatory roles of CD95/CD95L may provide attractive therapeutic options for patients with chronic inflammatory disorders or cancer. This review discusses the roles of the CD95/CD95L pair in cell migration and metastasis.
\end{abstract}

Keywords: Apoptosis, calcium, cytoskeleton, migration, TNF. 


\section{Introduction}

Metastatic disease remains the main cause of mortality among cancer patients, accounting for $90 \%$ of cancer-associated deaths [1]. Improving our understanding of metastatic development is essential to improve the outcomes of cancer patients. Decades of cancer research have described metastasis as a multi-step process by which cancer cells disseminate from the primary tumor to surrounding tissues and distant organs. Metastatic spread is mediated by a biological sequence in which metastatic cells invade surrounding tissue, disseminate to blood and lymphatic vessels, survive in the blood circulation, extravasate through the vascular wall, and colonize new organs [2]. This complex process implies that metastatic cells harbor distinct capacities that can be activated sequentially for progression through the metastatic stages.

Primary tumors, which fuel metastatic development, are characterized by marked intratumoral heterogeneity. The origin of this cellular heterogeneity is mainly explained by the hierarchical organization of tumor tissues, where several subpopulations of self-renewing cancer stem cells (CSCs) maintain the long-term oligoclonal nature of the neoplasm [3]. A direct consequence is the pivotal role of CSCs in leading clinical evolution and metastatic progression [4-6]. Growing evidence indicates that CD95 is a key regulator of metastatic spread. Accordingly, this so-called death receptor is involved in the migration of cancer cells in triple-negative breast cancers (TNBCs) [7] and glioblastoma [8] as well as the survival and regulation of CSC fate [9].

Although CD95 is considered the prototype of the death receptors, this paradigm has been challenged. It is becoming clear that, similar to tumor necrosis factor receptor (TNFR)-1, CD95 mediates non-apoptotic signaling pathways involved in many cellular processes including cell proliferation, survival, differentiation, and migration. This review focuses on the role of CD95 and its ligand CD95L in cell migration [10]. 


\section{Structural features of CD95 and its ligands}

Death receptors of the TNFR superfamily include TNFR1, Fas (CD95), death receptor 3 (DR3), TNF-related apoptosis-inducing ligand receptors 1 and 2 (TRAIL-R1 and TRAIL-R2), death receptor 6 (DR6), nerve growth factor receptor (NGFR), and ectodysplasin receptor (EDAR). These receptors share an intracellular death domain (DD) that is required for their apoptosisinducing activity [11]. Although the non-apoptotic functions of CD95 were reported soon after its cloning [12], they have been neglected over the years, as research efforts focused on deciphering the molecular basis of apoptosis induction by CD95 and the biological functions of CD95 in light of this role $[13,14]$.

CD95 is a 319 amino acid type I transmembrane glycoprotein $[15,16]$. This receptor harbors extracellular amino-terminal cysteine-rich domains (CRDs) $[17,18]$ that define its ligand specificity [19] and a conserved 80 amino acid sequence located in the cytoplasmic tail called the death domain (DD) that is necessary for the induction of apoptosis [20, 21]. Its corresponding ligand, CD95L (FasL/CD178), is a type II transmembrane protein with a cytoplasmic domain, a transmembrane domain, a stalk region, and a C-terminal TNF homology domain (THD). The THD mediates both homotrimerization of CD95L and binding to CD95 (Figure 1). This transmembrane ligand (m-CD95L) can be cleaved at the stalk region by several metalloproteases (MMPs), namely, MMP3, MMP7, MMP9, and a disintegrin and metalloprotease domain-containing protein (ADAM)-10 [22], or at the THD by plasmin [23]. The resulting soluble form of CD95L (s-CD95L) is released into the bloodstream as a homotrimer [24]. s-CD95L can interact with CD95 but does not induce cell death, and was initially thought to compete with its membrane-bound counterpart for CD95 binding [25, 26]. s-CD95L accumulates in the bloodstream of patients with various pathologic conditions, including certain cancers such as NK cell lymphomas [27] and TNBC, in which s-CD95L levels are associated with the risk of relapse [7]. 


\section{CD95-mediated cell signaling pathways}

The interaction of m-CD95L with CD95 leads to the recruitment of the adaptor protein Fasassociated protein with death domain (FADD) via homotypic DD-mediated interactions. FADD recruits the protease caspase- 8 and the long form of the regulator of apoptosis cellular FADDlike interleukin-1- $\beta$-converting enzyme-inhibitory protein $\left(\mathrm{cFLIP}_{\mathrm{L}}\right)$ via death effector domain (DED)-mediated interactions. Together, these proteins form the death-inducing signaling complex (DISC) (Figure 2) [28]. Tumor necrosis factor receptor-associated factor 2 (TRAF2) can interact with caspase-8 at the DISC [29]. TRAF2 induces K48-linked polyubiquitination of caspase- 8 and its rapid proteasomal degradation, protecting cells from death decisions [29]. In addition, TRAF2 orchestrates the implementation of non-apoptotic signaling pathways

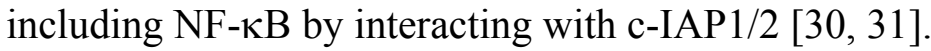

CD95 stimulation can induce apoptotic and non-apoptotic signaling pathways. The apoptotic signaling pathway is abrogated before completion in most cancer cells, suggesting that, in these cells, the CD95-mediated non-apoptotic signaling pathways including NF- $\mathrm{BB}$ and the p38, ERK, and JNK MAPKs promote cell proliferation, survival, and migration and cytokine production [32]. The CD95-mediated apoptotic and non-apoptotic signaling pathways share many factors such as the apoptotic factors FADD and caspase-8, which are also required for $\mathrm{NF}-\kappa \mathrm{B}$ activation upon $\mathrm{m}-\mathrm{CD} 95 \mathrm{~L}$ stimulation $[32,33]$. Unlike $\mathrm{m}-\mathrm{CD} 95 \mathrm{~L}, \mathrm{~s}-\mathrm{CD} 95 \mathrm{~L}$ does not efficiently recruit FADD and caspase-8, and thus fails to trigger the DISC and the subsequent apoptotic program. Our group and others showed that binding of the trimeric s-CD95L to CD95 induces the formation of an alternative signaling complex that results in cell migration, which we therefore designated as the motility-inducing signaling complex (MISC) (Figure 2) [7, 34]. MISC formation relies on the recruitment of phospholipase C $\gamma 1$ (PLC $\gamma 1$ ) to a membraneproximal intracellular domain of CD95 that has been designated calcium-inducing domain (CID). PLC $\gamma 1$ generates inositol triphosphate (IP3) and induces the release of endoplasmic 
reticulum (ER) calcium stores by activating IP3 receptors. The intracellular increase in calcium $\left(\mathrm{Ca}^{2+}\right)$ activates a store-operated current (SOC) through the plasma membrane $\mathrm{Ca}^{2+}$ channel ORAI1, resulting in $\mathrm{Ca}^{2+}$ entry close to CD95 and limiting the recruitment of FADD and caspase- 8 by activating protein kinase $\mathrm{C} \beta 2$ [35]. The recruitment and activation of NADPH oxidase 3 in the MISC triggers reactive oxygen species production, resulting in the activation of the src kinase designated c-yes and the subsequent induction of cell migration. This pathway has been observed in T cells, TNBC cells, and glioblastoma cells [8, 36, 37].

\section{CD95/CD95L and immune homeostasis}

Although the CD95/CD95L pair exerts pleiotropic effects in physiological and pathological contexts that will be discussed in this review, the main role of this couple involves the regulation of the adaptive immune response [38]. Lpr (lymphoproliferation) mice harbor a transposable element inserted into intron 2 of CD95 encoded by the $A P T 1$ gene that prematurely terminates CD95 transcription [39]. Gld (generalized lymphoproliferative disease) mice express a mutated CD95L in which the phenylalanine at position 273 is replaced by leucine (F273L), resulting in reduced affinity for CD95 [40]. Lprcg mice (lpr gene complementing gld) bear a mutation within the CD95 DD (N238V) that impinges on FADD recruitment and the induction of apoptosis [41]. Knock-in mice in which full length CD95L was replaced by its soluble counterpart revealed that the non-apoptotic ligand causes a severe lupus-like autoimmune disorder and promotes carcinogenesis [42]. These lupus-prone animal models, which are characterized by lymphadenopathy and splenomegaly, with an accumulation of $\mathrm{CD}^{+}{ }^{+} \mathrm{CD} 8$-CD4- $^{-}$doublenegative $\mathrm{T}(\mathrm{DNT})$ cells, revealed the pivotal role of the CD95L/CD95 pair in immune homeostasis. Consistent with these animal models, several germinal mutations of CD95 in humans are causative for autoimmune lymphoproliferative syndrome (ALPS) type Ia (also known as ALPS-FAS) [43]. ALPS patients show chronic lymphoproliferation, 
lymphadenopathy, and/or splenomegaly and an aberrant accumulation of DNT cells. Because they share many symptoms with lupus patients, ALPS patients are often initially diagnosed with lupus. ALPS-FAS patients exhibit heterozygous germline mutations in $A P T 1$ that are mainly located in the DD; such mutations prevent the induction of CD95-mediated apoptosis, whereas they allow non-apoptotic signaling [44, 45]. Animal models and ALPS patients confirm the pivotal role of CD95 in immune homeostasis, and suggest that its non-apoptotic signaling function contributes to inflammation and oncogenesis.

CD95 is responsible for immune contraction by mediating the apoptotic deletion of activated T cells in the periphery, a process called activation-induced cell death (AICD) [46-49]. Reexpression of CD95 in the T cells of lpr mice prevents lymphoproliferation associated with the accumulation of DNT cells but does not prevent autoimmunity $[50,51]$. On the other hand, loss of CD95L in $\mathrm{T}$ cells favors the accumulation of CD11 $\mathrm{c}^{+}$dendritic cells (DCs) and B cells, thereby contributing to prolonged antigen presentation, and is responsible for the autoimmune disorder [52]. In addition to its pro-apoptotic role, CD95L expression in memory CD4 ${ }^{+}$or CD8 ${ }^{+}$ T cells can induce a CD95-mediated PI3K/Akt signaling pathway in naïve T cells, altering their differentiation and activation. This represents an alternative route for CD95 to terminate the immune response in addition to AICD [53]. This CD95-mediated non-apoptotic process is designated "precocious differentiation".

\section{CD95-mediated cell migration and calcium $\left(\mathrm{Ca}^{2+}\right)$}

$\mathrm{Ca}^{2+}$ is a universal and versatile second messenger involved in the activation of pleiotropic signaling cascades $[54,55] . \mathrm{Ca}^{2+}$ pumps, channels, and exchangers and $\mathrm{Ca}^{2+}$-binding proteins present at the plasma membrane and in different cellular compartments (ER, lysosome, mitochondria, and Golgi apparatus) tightly regulate the $\left[\mathrm{Ca}^{2+}\right]_{\mathrm{cyt}}$, which is close to $100 \mathrm{nM}$ in the resting state $[56-60]$. In response to various stimuli, $\left[\mathrm{Ca}^{2+}\right]_{\mathrm{cyt}}$ can reach concentrations of 
$10 \mu \mathrm{M}$ and higher in microdomains, including the interface between the ER and the mitochondria (mitochondria-associated ER membrane or MAM) [56] or beneath the plasma membrane. This increased $\left[\mathrm{Ca}^{2+}\right]_{\mathrm{cyt}}$ can be evoked by mobilizing $\mathrm{Ca}^{2+}$ from intracellular stores, such as the ER and Golgi apparatus (Figure 3), or through $\mathrm{Ca}^{2+}$ entry from the extracellular environment via $\mathrm{Ca}^{2+}$ channels, such as Voltage-Gated Calcium (VGC) channels or SOC channels (Figure 3). Upon elevation of $\left[\mathrm{Ca}^{2+}\right]_{\mathrm{cyt}}$, energy-dependent active transporters, including pumps and exchangers, work to refill stores and reset $\mathrm{Ca}^{2+}$ levels to the resting state (Figure 3).

Most of the hallmarks of cancer, if not all, involve $\mathrm{Ca}^{2+}$ signaling, which mediates critical cellular processes such as therapeutic resistance [61], metastasis, bypass of apoptosis [62], and breast CSC enrichment [63]. CD95 engagement leads to a rapid, localized, and transient increase in $\left[\mathrm{Ca}^{2+}\right]_{\mathrm{cyt}}[64-66]$, which negatively controls CD95 apoptotic signaling [35], and promotes cell migration [34] and metastasis [7] through a c-yes/PLC $\gamma 1 /$ IP3/SOC channels/Ca ${ }^{2+} / \mathrm{PI} 3 \mathrm{~K}$ signal (Figures 2 and 3). The versatility of $\mathrm{Ca}^{2+}$ as an intracellular messenger stems largely from its complex spatiotemporal organization of the $\mathrm{Ca}^{2+}$ signals.

\section{Spatiotemporal calcium patterns}

$\mathrm{Ca}^{2+}$ signaling regulates multiple aspects of adaptive metastatic cancer cell behaviors, including migration, local angiogenesis induction, intravasation, and epithelial-mesenchymal transition (EMT) [67]. EMT is a central process required for normal embryonic development that not only contributes to metastatic dissemination [68], but is also involved in the chemotherapy resistance of cancer cells [69].

$\left[\mathrm{Ca}^{2+}\right]_{\text {cyt }}$ plays a key role in directional sensing, as oscillations in $\left[\mathrm{Ca}^{2+}\right]_{\text {cyt }}$ activate cytoskeletal remodeling, actin contraction, and focal adhesion (FA) turnover necessary for changes in contractility and directional movement (Figures 3 and 4). Cell movement begins with the 
formation of protrusions of the cell membrane (lamellipodia, filopodia, and podosomes), followed by the establishment of new FAs at the leading edge to anchor the cytoskeleton to the extracellular matrix (ECM). Traction forces move the cell forward, and the cycle ends with disassembly of the FA at the cell rear $[70,71]$. Most of these events are spatiotemporally regulated by $\mathrm{Ca}^{2+}$ signaling $[72,73]$. Indeed, oscillations of cytosolic $\mathrm{Ca}^{2+}$ induce actin remodeling through the activation of the small GTPases RhoA, cdc42, and Rac1, which are activated in cells exposed to s-CD95L [74] (Figure 3). During the rear-to-end retraction phase, actomyosin contraction is regulated by phosphorylation of the myosin light chain (MLC) mediated by the calmodulin $\mathrm{Ca}^{2+}$-dependent kinase MLCK (Figure 3) [67, 75]. Finally, the disassembly of the FA is controlled by calpains, which are $\mathrm{Ca}^{2+}$-dependent proteases (Figure 3) [76]. During migration, polarized cells exhibit a cytosolic $\mathrm{Ca}^{2+}$ gradient in which $\mathrm{Ca}^{2+}$ concentration is low at the leading edge [77]. This gradient is produced by increased activity of the plasma membrane calcium ATPases (PMCA pumps) at the leading edge to extrude intracellular $\mathrm{Ca}^{2+}[78]$ (Figure 4). This low intracellular $\mathrm{Ca}^{2+}$ concentration allows the different components of the cell migration machinery to respond to local and transient $\mathrm{Ca}^{2+}$ spikes called "Ca ${ }^{2+}$ flickers" at the front of the migrating cells (Figures 3 and 4). These "pulses" locally promote the disassembly of FA proteins [79], and steer the migrating cell in the direction of the chemoattractant [80]. In migrating cells, mitochondria actively move along cytoskeletal filaments to different cellular topographies with high energetic demands (Figure 4). In addition to ATP production, one of the main functional roles attributed to mitochondria is the ability to spatially remodel intracellular $\mathrm{Ca}^{2+}$ signaling. Accordingly, inhibition of the mitochondrial $\mathrm{Ca}^{2+}$ uniporter (MCU) by ruthenium red or specific small interfering RNAs induces mitochondrial depolarization in the triple-negative breast adenocarcinoma cell line MDA-MB-231, inhibiting SOC Entry (SOCE) through Orai1/STIM1 channels and abrogating cancer cell migration [81]. In summary, hotspots of $\mathrm{Ca}^{2+}$ are crucial for cell migration and cell steering, and rely on many 
cellular factors including SOCE $[78,79]$ and the activity of stretch-activated calcium channels (SAC) $[77,80]$.

\section{Non-apoptotic effect of CD95 engagement and $\mathrm{Ca}^{2+}$ response}

Many highly invasive cancer cell types possess specialized matrix-degrading organelles called invadopodia $[82,83]$. Invadopodia are dynamic actin-based cell protrusions composed of an actin core surrounded by integrins and actin-associated proteins. The assembly of invadopodia is initiated in response to the focal generation of phosphatidylinositol bi and trisphosphate $\left(\mathrm{PIP}_{2}\right.$ and $\left.\mathrm{PIP}_{3}\right)$ and the activation of the nonreceptor tyrosine kinase Src [84-86]. The assembled invadopodia recruit proteolytic enzymes, such as membrane type 1 (MT1)-matrix metalloproteinase (MMP), MMP2, and MMP9, via localized $\mathrm{Ca}^{2+}$ influx through SAC [87-89] and extracellular medium acidification through the $\mathrm{Na}^{+} / \mathrm{H}^{+}$exchanger $\mathrm{NHE} 1$ [90] to facilitate the focal degradation of the ECM and cell invasion [91] (Figure 4). The membrane-bound apoptotic CD95L is cleaved by these MMPs [92] to generate the pro-migratory s-CD95L, which in turn induces CD95-mediated NHE1 activation [74].

s-CD95L induces the formation of migrating pseudopods at the leading edge of which the engaged CD95 and SOC channels are capped [34]. Therefore, the $\mathrm{Ca}^{2+}$ response that promotes CD95-mediated cell motility does not display a homogeneous cytosolic distribution, but instead results in $\mathrm{Ca}^{2+}$ microdomains localized at the leading edge of the cell protrusion emitted by the migrating cells [34]. CD95L-induced cell migration depends, at least in part, on another $\mathrm{Ca}^{2+}$ microdomain between the ER and mitochondria called MAM. The anti-apoptotic factors Bcl-2 and BclxL, which are localized in these intracellular compartments, collaborate to induce CD95-mediated mitochondrial $\mathrm{Ca}^{2+}$ upload, increasing ATP production and thereby promoting cell migration [93]. Capping of CD95 is associated with F-actin polarization in activated T cells, and this process occurs independently of the apoptotic program because inhibition of actin 
polymerization using cytochalasin D prevents CD95 capping without affecting DISC formation [94]. CD95 capping requires activation of the serine/threonine kinase Rho kinase (ROCK) [94], which is also necessary to activate NHE1 in cells exposed to s-CD95L [74]. In the fibroblast cell line PS120, s-CD95L enhances cell migration by activating NHE1 via Akt and RhoAdependent but $\mathrm{Ca}^{2+}$-independent pathways [74]. This does not rule out the participation of STIM1/Orai1 in CD95L-mediated PS120 cell migration, and $\mathrm{Ca}^{2+}$-independent effects of STIM1/Orail on cell migration were recently described in relation to the RhoA/ROCK/MLC transduction pathway [95-97]. Interaction of these proteins, which colocalize in the CD95 cap, would be sufficient to trigger the effects of CD95L on cell migration.

NHE1 catalyzes an electroneutral exchange of extracellular $\mathrm{Na}^{+}$for intracellular $\mathrm{H}^{+}$, and its activity is necessary for cell migration $[98,99]$. The NHE1-driven increase in intracellular $\mathrm{pH}$ affects cell migration by changing the structure of cofilin, presumably through the deprotonation of $\mathrm{His}^{133}$, and impairing its recruitment by phosphatidylinositol 4,5-bisphosphate $\left(\mathrm{PI}_{(4,5)} \mathrm{P}_{2}\right)$, thus stimulating its actin-severing activity [100] (Figure 4). Increased assembly of a branched actin filament network requires filament severing to increase the abundance of actinfree barbed ends, and is a driving force for membrane protrusion through a cofilin and Arp2/3dependent mechanism [101] (Figure 4). Cortactin recruits the adaptor protein Nck1, which in turn binds N-WASP, and cofilin [102]. This molecular complex is disrupted through src kinasedependent phosphorylation of cortactin and NHE1-dependent $\mathrm{pH}$ increase [103] to release cofilin, which promotes actin polymerization and invadopodia formation (Figure 4). NHE1 activity is also instrumental for the activation of central determinants of cell polarity such as cdc42 [98]. Activation of PLC $\gamma$, which hydrolyzes $\mathrm{PI}_{(4,5)} \mathrm{P}_{2}$, is necessary for cofilin-dependent actin-free barbed end formation [104]. Interaction of s-CD95L with CD95 triggers the rapid accumulation of the receptor at the leading edge of motile cells $[34,105]$, and activates PLC $\gamma 1$ [34] and NHE1 [74], engendering a cell migration program that requires cofilin [106]. 
Activation of cell migration and survival mediated by CD95 relies on the recruitment of receptor tyrosine kinases (RTKs) including epidermal growth factor receptor (EGFR) [7, 107] and platelet-derived growth factor receptor (PDGFR) [106] and the subsequent activation of members of the src kinase family.

\section{Adhesion and regulation of CD95-mediated cell death}

We and others observed that CD95L is ectopically expressed by endothelial cells covering blood vessels in inflamed organs of lupus patients [37] and in tumor tissues [7, 108], suggesting that CD95L could serve as a barrier [108], a chemoattractant following its shedding by metalloproteases [37, 109], or an adhesion molecule for the recruitment of neutrophils [110]. Indeed, Coukos and colleagues report that CD95L expression by endothelial cells in tumor tissues represents a physical barrier, killing $\mathrm{CD} 8^{+} \mathrm{T}$ cells while sparing $\mathrm{T}$ regulatory (Treg) cells, whose accumulation in the tumor might cause an immunosuppressive environment [108]. Nonetheless, the transmembrane CD95L at the surface of endothelial cells also has nonapoptotic functions, as it promotes the binding and recruitment of myeloid cells by inducing rolling, adhesion, and transmigration processes [110]. Therefore, CD95L expression by endothelial cells is instrumental for mounting an efficient anti-infectious response [110]. After metalloprotease-mediated cleavage, the generation of a s-CD95L gradient promotes the trafficking of pro-inflammatory Th17 cells in inflamed organs of lupus patients, thereby contributing to aggravate their clinical symptoms [37]. This s-CD95L gradient in TNBC patients favors migration of cancer cells and increases the risk of metastasis [7].

The expression of plasminogen activator inhibitor-1 (PAI-1) by endothelial cells is a marker of poor prognosis in colorectal cancer [111]. CD95L expression by endothelial cells controls neoangiogenesis through a PAI-1-dependent mechanism [23]. PAI-1 is the inhibitor of urokinasetype plasminogen activator (uPA), which converts plasminogen into its active form, plasmin. 
Plasmin in turn can cleave CD95L in its trimerization domain at Arg144-Lys 145, releasing a cytotoxic ligand that eliminates endothelial cells and abrogates neo-angiogenesis [23]. PAI-1 overexpression inhibits this process and promotes neovessel formation in cancers.

Overall, these studies raise the question of the exact role of CD95L in endothelial cells covering neovessels, and suggest that the co-expression of certain metalloproteases/PAI-1 may account for these pleiotropic roles.

Alteration of adherens junctions in epithelia is associated with loss of cell-cell contacts, an initial step in EMT and the metastatic dissemination of carcinoma cells [112]. Loss of these contacts generates a cell death program that depends on CD95 [113]. Hueber et al. recently showed that the C-terminal domain of CD95 is important for the distribution of the receptor within adherens junctions in epithelial cells [113]. This region of CD95 also interacts with the polarity molecule Dlg1, thereby preventing DISC formation [113]. Depolarization of CD95 and its dissociation from Dlg1 and E-cadherin might represent a control mechanism to eliminate abnormal cells within epithelial tissues, thereby preventing the initial step of metastatic dissemination. The ERM proteins (ezrin, radixin, and moesin) are found in the microvilli, filopodia, membrane ruffles, and cell-to-cell contact sites, where they colocalize with actin and connect various cell-surface proteins to the actin cytoskeleton (Figure 4). Similar to Dlg1, ezrin interacts with the C-terminal PDZ-binding site of CD95 [105]; however, Dlg1 binding to CD95 prevents DISC formation, whereas ezrin interaction with the receptor is instrumental for implementing the apoptotic program, at least in activated $\mathrm{CD}^{+} \mathrm{T}$ cells [105].

The link between CD95 and the cytoskeleton could reflect different stages of tumor development. Peter et al. showed that cancer cells with mesenchymal markers have a strong link between CD95 and the actin cytoskeleton and are sensitive to actin disruptors (i.e., cytochalasin D), whereas epithelial cells exhibit a stronger association between CD95 and microtubule structures and are sensitive to microtubule-disrupting compounds [114]. 
Most of the studies on the cytoskeleton and CD95 focus on the apoptotic outcome and neglect to evaluate the obvious effect on cell migration and invasiveness.

\section{Cell migration and the apoptotic machinery}

Although caspase-8 is well-known as an apoptotic inducer, this zymogen also acts through its scaffolding function to drive cytokine production in various cancer cell lines upon m-CD95L stimulation [115]. Production of pro-inflammatory chemokines in dying cells results in the recruitment of monocytes and neutrophils that engulf the dying cells expressing the "find me" signal [116]. As recently detailed elsewhere [92], Src kinases phosphorylate multiple targets, and also mediate the recruitment of various RTKs such as EGFR into close proximity to CD95 through mechanisms that remain to be elucidated. MISC formation leads to the activation of the PI3K/Akt pathway, which is instrumental for cancer cell migration [7]. Although caspase8 is not readily detected in the MISC by western blotting, it can be phosphorylated by Src on Y380, a molecular event that not only limits its activation but also promotes the recruitment and activation of the p85 regulatory subunit, initiating PI3K/Akt activation [117-119]. Although the CID is required for inducing the CD95-mediated $\mathrm{Ca}^{2+}$ response, PI3K activation is DD-dependent [34], suggesting that the CD95-mediated non-apoptotic signal stems from both the CID and the DD.

Together with caspase-8, TRAF2 may also contribute to the CD95-mediated migration process. TRAF2 overexpression triggers a positive feedback loop in pancreatic tumor cells, because exposure to CD95L activates the NF- $\kappa \mathrm{B}$ signal, which in turn fuels TRAF2 overexpression in tumor cells [120]. In the presence of CD95L, pancreatic tumor cells overexpressing TRAF2 induce the secretion of MMP2 and MMP9, uPA, and IL-8, factors involved in the invasive process. Although partial TRAF2-dependent inhibition of caspase- 8 activation at the DISC level is required for the secretion of IL- 8 and UPA and cell migration, complete abrogation of 
caspase activity using the pharmacologic inhibitor zVAD-fmk blocks invasiveness, strongly supporting that the fine-tuned regulation of caspase activity orchestrates the cellular response $[120]$.

\section{Cancer stem cells and CD95}

Increasing evidence supports the existence of functionally distinct subsets of CSCs within primary tumors with tumor-propagating and/or metastatic capacity [121]. This functional heterogeneity within the CSC population was first described in pancreatic cancers, in which CXCR4 expression defines two different $\mathrm{CD}_{133^{+}} \mathrm{CSC}$ subsets. The CD133 ${ }^{+} \mathrm{CXCR} 4^{-}$ population solely maintains the tumorigenic potential of the primary tumor, whereas the $\mathrm{CD} 133^{+} \mathrm{CXCR} 4^{+}$cell population is essential for metastatic development [122]. A similar subpopulation of colorectal CSCs expressing CD26 was identified as the population responsible for liver metastasis, and was predictive of distant metastasis in patients [123]. The origin of this functional heterogeneity within the CSC population recently evolved with the notion of CSC state plasticity. In this regard, metastatic CSCs and non-metastatic CSCs may not be two distinct populations, but rather represent a gradient of stem cell programs that are expressed at higher or lower levels in response to intracellular and intercellular signals [124]. EMT plays an essential role in these CSC transition states $[125,126]$. This concept was demonstrated by Liu et al., who showed that breast CSCs are highly plastic, transiting between two different cell states: a more proliferative epithelial-like state characterized by expression of ALDH, and a more invasive mesenchymal-like state characterized by the expression of the $\mathrm{CD} 44^{+} / \mathrm{CD} 24^{-}$ phenotype [127]. Over the last decade, the connection between CSCs and EMT attracted considerable attention [128]. Studies initially suggested that overexpression of EMT transcription factors was sufficient to generate CSCs $[129,130]$. However, cumulative clues indicate that cancer stemness and EMT are in fact convergent concepts by which the EMT 
process confers CSCs the ability to switch between two CSC states. Although recent findings raise doubts about the critical role of EMT during metastasis in mouse models of breast and pancreatic cancers $[69,131]$, evidence supports that EMT is alternatively switched on during the first step of metastatic spread (tissue invasion, circulation in blood, and extravasation), and then switched off to allow the metastatic colonization of new organs. This cell plasticity was directly observed by intravital microscopy, confirming the role of epithelial-mesenchymal plasticity in metastatic development [132].

In this context, a thorough understanding of the associated tumor microenvironment factors that control the balance between the different CSC states is required to improve our understanding of metastatic disease. Emerging evidence suggests that tumor-infiltrated immune cells may play this role, bringing back the "seed and soil" hypothesis of S. Paget [133]. Myeloid-derived suppressor cells (MDSCs) are a subset of immature myeloid cells that can be recruited to tumor sites and display immunosuppressive activity [134]. Ouzounova et al. used mammary tumor models to demonstrate that monocytic (M-MDSCs) and granulocytic (G-MDSCs) subsets of MDSCs regulate spatiotemporal tumor cell plasticity. M-MDSCs facilitate tumor cell dissemination from the primary site by inducing EMT, whereas pulmonary G-MDSC infiltrates support metastatic colonization by reverting the EMT process [135]. Consistent with this idea, the IL-1 $\beta$ inflammatory response facilitates invasion and extravasation of metastatic-initiating cells by promoting EMT, and this signaling must be shut down at the metastatic site to induce EMT reversion and secondary tumor formation [136]. Similarly, neutrophils specifically support metastatic initiation by priming pre-metastatic sites, and neutrophil-derived leukotrienes aid the colonization of distant tissues by selectively expanding the sub-pool of cancer cells that acquire a stemness phenotype and retain high tumorigenic potential [137].

In mice, MDSCs are characterized by the expression of CD11 $\mathrm{b}^{+} \mathrm{Gr}-1^{+}$cell markers; G-MDSCs show $\mathrm{CD} 11 \mathrm{~b}^{+} \mathrm{Ly} 6 \mathrm{G}^{+} \mathrm{Gr}-1^{\text {High }}$ staining, whereas M-MDSCs show a CD $11 b^{+}$Ly6C $\mathrm{C}^{+} \mathrm{Gr}-1^{\text {Low }}$ 
phenotype. The homeostasis of these myeloid cells relies on CD95L expression because loss of CD95L in mice leads to an increase in these populations [138]. Resistance to immunotherapy including the checkpoint inhibitors anti-CTLA4 and anti-PD1 in a melanoma mouse model is associated with increased infiltration of G-MDSCs expressing CD95L, which eliminates activated anti-tumor $\mathrm{CD} 95^{\text {high }}$-expressing $\mathrm{CD}^{+} \mathrm{T}$ cells [139]. Another study showed that CD95L deficiency skews tumor-infiltrating MDSCs from G-MDSCs to the M-MDSC subset, which displays high immunosuppressive activity mostly through the overexpression of PD-L1 [138]. These results emphasize the pivotal role of the CD95/CD95L pair in modulating the immune landscape by recruiting immunosuppressive cells within the primary tumor and/or participating in the elimination of anti-tumor $\mathrm{CD}^{+} \mathrm{T}$ cells. Nonetheless, the cells in tumor tissues that express CD95L and modulate the "soil" and, the CD95-dependent molecular mechanisms involved in the cancer/immune cell unbalance remain to be elucidated; recent data indicate that endothelial cells covering neovessels could represent the major source of CD95L $[7,108]$,

Marcus Peter and colleagues proposed that CD95 stimulation can also modulate the phenotype of the "seed" itself. Accordingly, CD95 stimulation in various cancers (i.e., colon, breast, and renal cancer cell lines) induces a conversion from non-CSCs to CSCs through an apoptoticindependent program, and in addition renders these cells resistant to the CD95-mediated apoptotic program [140]. From a molecular standpoint, CD95 stimulation in cancer cells induces the secretion of type I interferons (IFN $\alpha$ or IFN $\beta$ ), which interact with IFN type I receptors (IFNAR1 and IFNAR2) and activate STAT1-promoting cancer stemness [9]. These experiments confirmed that CD95 is not a receptor uniquely able to implement cell death; however, the downstream molecular mechanisms controlling the implementation of cell death at the expense of this non-apoptotic and stemness response and vice versa remain unclear. 
Taken together, these studies suggest that the "seed and soil" concept needs to be revised to fit the concept of CSC state plasticity, and the CD95/CD95L pair might affect both seed and soil properties affecting cancer cell fate decisions and function. This assumption, if validated, will strengthen the use of CD95/CD95L inhibitors to improve cancer care.

\section{Conclusion and therapeutic perspectives}

Spatiotemporally coordinated calcium gradients generated by SOCs and SACs, calcium efflux systems, and calcium microdomains orchestrate cellular behaviors as complex as directional cell movement. CD95 participates in this phenomenon by activating localized $\mathrm{Ca}^{2+}$ influx through SOCs. The effect of CD95 engagement on SAC activity has not been described to date; however, CD95 is linked to structures such as lipid rafts/caveolae or the cytoskeleton, which contribute to the activation of these channels. In muscle fibers, for example, similarities in electrophysiological properties and sensitivity to pharmacological inhibitors suggest that SOC and SAC belong to the same channel population or share common constituents, suggesting that both channels express the TRPC1 protein [141]. This mechanosensitive SOC regulates the cell

polarity involved in the migration of human bone osteosarcoma cells [142] and breast cancer cells (for review, see [143]). Future investigation of a potential molecular link between CD95 and the mechanosensitive channels would open new avenues to better understand the relationship between cell migration and the pathophysiological functions of the so-called death receptor.

The capability of proteinases to catalytically cleave substrate proteins post-synthesis is essential for sustaining life in all of its forms, from viruses to humans. Limited, site-specific proteolysis is an important post-translational modification, especially because this post-translational modification, in contrast to others, is irreversible under physiological conditions. The fact that two forms of CD95L exist and are associated with the presence or absence of MMPs raises the 
question of what and where metalloproteases cleave CD95L. Similar to TNF, which is processed by TACE (ADAM-17) [144, 145] to release a soluble and inflammatory factor, CD95L-cleaving MMP(s) cause a signaling shift that transforms the apoptotic ligand into a proinflammatory factor. Targeting soluble CD95L, its non-apoptotic signaling pathways, or the MMPs responsible for its cleavage may represent a novel therapeutic strategy to alleviate clinical symptoms in chronic inflammatory disorders such as lupus or to prevent metastatic dissemination in cancer patients. In this context, a "niche therapy" based on CD95-oriented targeting of the CSC-niche signals may be a potent alternative to prevent tumor progression [146]. 
Acknowledgements:

This work was supported by INCa PLBIO, Ligue Contre le Cancer, Fondation ARC, ANR PRCE, Canceropole GO and Region Bretagne. 


\section{REFERENCES}

[1] A.W. Lambert, D.R. Pattabiraman, R.A. Weinberg, Emerging Biological Principles of Metastasis, Cell 168(4) (2017) 670-691.

[2] G.P. Gupta, J. Massague, Cancer metastasis: building a framework, Cell 127(4) (2006) 67995.

[3] A. Kreso, J.E. Dick, Evolution of the cancer stem cell model, Cell Stem Cell 14(3) (2014) 27591.

[4] E. Charafe-Jauffret, C. Ginestier, F. Iovino, C. Tarpin, M. Diebel, B. Esterni, G. Houvenaeghel, J.M. Extra, F. Bertucci, J. Jacquemier, L. Xerri, G. Dontu, G. Stassi, Y. Xiao, S.H. Barsky, D. Birnbaum, P. Viens, M.S. Wicha, Aldehyde dehydrogenase 1-positive cancer stem cells mediate metastasis and poor clinical outcome in inflammatory breast cancer, Clin Cancer Res 16(1) (2010) 45-55.

[5] C. Ginestier, M.H. Hur, E. Charafe-Jauffret, F. Monville, J. Dutcher, M. Brown, J. Jacquemier, P. Viens, C.G. Kleer, S. Liu, A. Schott, D. Hayes, D. Birnbaum, M.S. Wicha, G. Dontu, ALDH1 is a marker of normal and malignant human mammary stem cells and a predictor of poor clinical outcome, Cell Stem Cell 1(5) (2007) 555-67.

[6] A. Merlos-Suarez, F.M. Barriga, P. Jung, M. Iglesias, M.V. Cespedes, D. Rossell, M. Sevillano, X. Hernando-Momblona, V. da Silva-Diz, P. Munoz, H. Clevers, E. Sancho, R. Mangues, E. Batlle, The intestinal stem cell signature identifies colorectal cancer stem cells and predicts disease relapse, Cell Stem Cell 8(5) (2011) 511-24.

[7] M. Malleter, S. Tauzin, A. Bessede, R. Castellano, A. Goubard, F. Godey, J. Leveque, P. Jezequel, L. Campion, M. Campone, T. Ducret, G. MacGrogan, L. Debure, Y. Collette, P. Vacher, P. Legembre, CD95L cell surface cleavage triggers a prometastatic signaling pathway in triplenegative breast cancer, Cancer Res 73(22) (2013) 6711-21.

[8] S. Kleber, I. Sancho-Martinez, B. Wiestler, A. Beisel, C. Gieffers, O. Hill, M. Thiemann, W. Mueller, J. Sykora, A. Kuhn, N. SchregImann, E. Letellier, C. Zuliani, S. Klussmann, M. Teodorczyk, H.J. Grone, T.M. Ganten, H. Sultmann, J. Tuttenberg, A. von Deimling, A. RegnierVigouroux, C. Herold-Mende, A. Martin-Villalba, Yes and PI3K bind CD95 to signal invasion of glioblastoma, Cancer Cell 13(3) (2008) 235-48.

[9] A.S. Qadir, P. Ceppi, S. Brockway, C. Law, L. Mu, N.N. Khodarev, J. Kim, J.C. Zhao, W. Putzbach, A.E. Murmann, Z. Chen, W. Chen, X. Liu, A.R. Salomon, H. Liu, R.R. Weichselbaum, J. Yu, M.E. Peter, CD95/Fas Increases Stemness in Cancer Cells by Inducing a STAT1-Dependent Type I Interferon Response, Cell reports 18(10) (2017) 2373-2386.

[10] L. Chen, S.M. Park, A.V. Tumanov, A. Hau, K. Sawada, C. Feig, J.R. Turner, Y.X. Fu, I.L. Romero, E. Lengyel, M.E. Peter, CD95 promotes tumour growth, Nature 465(7297) (2010) 4926.

[11] C. Dostert, M. Grusdat, E. Letellier, D. Brenner, The TNF Family of Ligands and Receptors: Communication Modules in the Immune System and Beyond, Physiol Rev 99(1) (2019) 115160.

[12] M.R. Alderson, R.J. Armitage, E. Maraskovsky, T.W. Tough, E. Roux, K. Schooley, F. Ramsdell, D.H. Lynch, Fas transduces activation signals in normal human T lymphocytes, J Exp Med 178(6) (1993) 2231-5.

[13] B.C. Trauth, C. Klas, A.M. Peters, S. Matzku, P. Möller, W. Falk, K.M. Debatin, P.H. Krammer, Monoclonal antibody-mediated tumor regression by induction of apoptosis, Science 245(4915) (1989) 301-5. 
[14] S. Yonehara, A. Ishii, M. Yonehara, A cell-killing monoclonal antibody (anti-Fas) to a cell surface antigen co-downregulated with the receptor of tumor necrosis factor, J Exp Med 169(5) (1989) 1747-56.

[15] N. Itoh, S. Yonehara, A. Ishii, M. Yonehara, S. Mizushima, M. Sameshima, A. Hase, Y. Seto, S. Nagata, The polypeptide encoded by the CDNA for human cell surface antigen Fas can mediate apoptosis, Cell 66(2) (1991) 233-43.

[16] A. Oehm, I. Behrmann, W. Falk, M. Pawlita, G. Maier, C. Klas, M. Li-Weber, S. Richards, J. Dhein, B.C. Trauth, Purification and molecular cloning of the APO-1 cell surface antigen, a member of the tumor necrosis factor/nerve growth factor receptor superfamily. Sequence identity with the Fas antigen, J Biol Chem 267(15) (1992) 10709-15.

[17] C.A. Smith, T. Farrah, R.G. Goodwin, The TNF receptor superfamily of cellular and viral proteins: activation, costimulation, and death, Cell 76(6) (1994) 959-62.

[18] R.M. Locksley, N. Killeen, M.J. Lenardo, The TNF and TNF receptor superfamilies: integrating mammalian biology, Cell 104(4) (2001) 487-501.

[19] J.L. Bodmer, P. Schneider, J. Tschopp, The molecular architecture of the TNF superfamily, Trends in biochemical sciences 27(1) (2002) 19-26.

[20] N. Itoh, S. Nagata, A novel protein domain required for apoptosis. Mutational analysis of human Fas antigen, J Biol Chem 268(15) (1993) 10932-7.

[21] L.A. Tartaglia, T.M. Ayres, G.H. Wong, D.V. Goeddel, A novel domain within the $55 \mathrm{kd}$ TNF receptor signals cell death, Cell 74(5) (1993) 845-53.

[22] J.P. Guegan, P. Legembre, Nonapoptotic functions of Fas/CD95 in the immune response, FEBS J 285(5) (2018) 809-827.

[23] K. Bajou, H. Peng, W.E. Laug, C. Maillard, A. Noel, J.M. Foidart, J.A. Martial, Y.A. DeClerck, Plasminogen activator inhibitor-1 protects endothelial cells from FasL-mediated apoptosis, Cancer Cell 14(4) (2008) 324-34.

[24] M. Tanaka, T. Itai, M. Adachi, S. Nagata, Downregulation of Fas ligand by shedding, Nat Med 4(1) (1998) 31-6.

[25] T. Suda, H. Hashimoto, M. Tanaka, T. Ochi, S. Nagata, Membrane Fas ligand kills human peripheral blood T lymphocytes, and soluble Fas ligand blocks the killing, J Exp Med 186(12) (1997) 2045-50.

[26] P. Schneider, N. Holler, J.L. Bodmer, M. Hahne, K. Frei, A. Fontana, J. Tschopp, Conversion of membrane-bound Fas(CD95) ligand to its soluble form is associated with downregulation of its proapoptotic activity and loss of liver toxicity, J Exp Med 187(8) (1998) 1205-13.

[27] M. Tanaka, T. Suda, K. Haze, N. Nakamura, K. Sato, F. Kimura, K. Motoyoshi, M. Mizuki, S. Tagawa, S. Ohga, K. Hatake, A.H. Drummond, S. Nagata, Fas ligand in human serum, Nat Med 2(3) (1996) 317-22.

[28] F.C. Kischkel, S. Hellbardt, I. Behrmann, M. Germer, M. Pawlita, P.H. Krammer, M.E. Peter, Cytotoxicity-dependent APO-1 (Fas/CD95)-associated proteins form a death-inducing signaling complex (DISC) with the receptor, Embo J 14(22) (1995) 5579-88.

[29] F. Gonzalvez, D. Lawrence, B. Yang, S. Yee, R. Pitti, S. Marsters, V.C. Pham, J.P. Stephan, J. Lill, A. Ashkenazi, TRAF2 Sets a threshold for extrinsic apoptosis by tagging caspase-8 with a ubiquitin shutoff timer, Mol Cell 48(6) (2012) 888-99.

[30] M. Rothe, M.G. Pan, W.J. Henzel, T.M. Ayres, D.V. Goeddel, The TNFR2-TRAF signaling complex contains two novel proteins related to baculoviral inhibitor of apoptosis proteins, Cell 83(7) (1995) 1243-52.

[31] H. Wajant, P. Scheurich, TNFR1-induced activation of the classical NF-kappaB pathway, FEBS J 278(6) (2011) 862-76. 
[32] B.C. Barnhart, P. Legembre, E. Pietras, C. Bubici, G. Franzoso, M.E. Peter, CD95 ligand induces motility and invasiveness of apoptosis-resistant tumor cells, Embo J 23(15) (2004) 3175-85.

[33] S. Kreuz, D. Siegmund, J.J. Rumpf, D. Samel, M. Leverkus, O. Janssen, G. Hacker, O. Dittrich-Breiholz, M. Kracht, P. Scheurich, H. Wajant, NFkappaB activation by Fas is mediated through FADD, caspase-8, and RIP and is inhibited by FLIP, J Cell Biol 166(3) (2004) 369-80.

[34] S. Tauzin, B. Chaigne-Delalande, E. Selva, N. Khadra, S. Daburon, C. Contin-Bordes, P. Blanco, J. Le Seyec, T. Ducret, L. Counillon, J.F. Moreau, P. Hofman, P. Vacher, P. Legembre, The naturally processed CD95L elicits a c-yes/calcium/PI3K-driven cell migration pathway, PLoS Biol 9(6) (2011) e1001090.

[35] N. Khadra, L. Bresson-Bepoldin, A. Penna, B. Chaigne-Delalande, B. Segui, T. Levade, A.M. Vacher, J. Reiffers, T. Ducret, J.F. Moreau, M.D. Cahalan, P. Vacher, P. Legembre, CD95 triggers Orai1-mediated localized Ca2+ entry, regulates recruitment of protein kinase $C$ (PKC) beta2, and prevents death-inducing signaling complex formation, Proc Natl Acad Sci U S A 108(47) (2011) 19072-7.

[36] F.J. Hoogwater, M.W. Nijkamp, N. Smakman, E.J. Steller, B.L. Emmink, B.F. Westendorp, D.A. Raats, M.R. Sprick, U. Schaefer, W.J. Van Houdt, M.T. De Bruijn, R.C. Schackmann, P.W. Derksen, J.P. Medema, H. Walczak, I.H. Borel Rinkes, O. Kranenburg, Oncogenic K-Ras turns death receptors into metastasis-promoting receptors in human and mouse colorectal cancer cells, Gastroenterology 138(7) (2010) 2357-67.

[37] A. Poissonnier, D. Sanseau, M. Le Gallo, M. Malleter, N. Levoin, R. Viel, L. Morere, A. Penna, P. Blanco, A. Dupuy, F. Poizeau, A. Fautrel, J. Seneschal, F. Jouan, J. Ritz, E. Forcade, N. Rioux, C. Contin-Bordes, T. Ducret, A.M. Vacher, P.A. Barrow, R.J. Flynn, P. Vacher, P. Legembre, CD95-Mediated Calcium Signaling Promotes T Helper 17 Trafficking to Inflamed Organs in Lupus-Prone Mice, Immunity 45(1) (2016) 209-23.

[38] A. Strasser, P.J. Jost, S. Nagata, The many roles of FAS receptor signaling in the immune system, Immunity 30(2) (2009) 180-92.

[39] R. Watanabe-Fukunaga, C.I. Brannan, N.G. Copeland, N.A. Jenkins, S. Nagata, Lymphoproliferation disorder in mice explained by defects in Fas antigen that mediates apoptosis, Nature 356(6367) (1992) 314-7.

[40] T. Takahashi, M. Tanaka, C.I. Brannan, N.A. Jenkins, N.G. Copeland, T. Suda, S. Nagata, Generalized lymphoproliferative disease in mice, caused by a point mutation in the Fas ligand, Cell 76(6) (1994) 969-76.

[41] A. Matsuzawa, T. Moriyama, T. Kaneko, M. Tanaka, M. Kimura, H. Ikeda, T. Katagiri, A new allele of the Ipr locus, Iprcg, that complements the gld gene in induction of lymphadenopathy in the mouse, J Exp Med 171(2) (1990) 519-31.

[42] L.A. O' Reilly, L. Tai, L. Lee, E.A. Kruse, S. Grabow, W.D. Fairlie, N.M. Haynes, D.M. Tarlinton, J.G. Zhang, G.T. Belz, M.J. Smyth, P. Bouillet, L. Robb, A. Strasser, Membrane-bound Fas ligand only is essential for Fas-induced apoptosis, Nature 461(7264) (2009) 659-63.

[43] S. Tauzin, L. Debure, J.F. Moreau, P. Legembre, CD95-mediated cell signaling in cancer: mutations and post-translational modulations, Cellular and molecular life sciences : CMLS 69(8) (2012) 1261-77.

[44] P. Legembre, B.C. Barnhart, L. Zheng, S. Vijayan, S.E. Straus, J. Puck, J.K. Dale, M. Lenardo, M.E. Peter, Induction of apoptosis and activation of NF-kappaB by CD95 require different signalling thresholds, EMBO Rep 5(11) (2004) 1084-9. 
[45] J. Desbarats, R.B. Birge, M. Mimouni-Rongy, D.E. Weinstein, J.S. Palerme, M.K. Newell, Fas engagement induces neurite growth through ERK activation and p35 upregulation, Nat Cell Biol 5(2) (2003) 118-25.

[46] M.R. Alderson, T.W. Tough, T. Davis-Smith, S. Braddy, B. Falk, K.A. Schooley, R.G. Goodwin, C.A. Smith, F. Ramsdell, D.H. Lynch, Fas ligand mediates activation-induced cell death in human T lymphocytes, J Exp Med 181(1) (1995) 71-7.

[47] J. Dhein, H. Walczak, C. Baumler, K.M. Debatin, P.H. Krammer, Autocrine T-cell suicide mediated by APO-1/(Fas/CD95), Nature 373(6513) (1995) 438-41.

[48] S.T. Ju, D.J. Panka, H. Cui, R. Ettinger, M. el-Khatib, D.H. Sherr, B.Z. Stanger, A. MarshakRothstein, Fas(CD95)/FasL interactions required for programmed cell death after T-cell activation, Nature 373(6513) (1995) 444-8.

[49] T. Brunner, R.J. Mogil, D. LaFace, N.J. Yoo, A. Mahboubi, F. Echeverri, S.J. Martin, W.R. Force, D.H. Lynch, C.F. Ware, et al., Cell-autonomous Fas (CD95)/Fas-ligand interaction mediates activation-induced apoptosis in T-cell hybridomas, Nature 373(6513) (1995) 441-4. [50] H. Fukuyama, M. Adachi, S. Suematsu, K. Miwa, T. Suda, N. Yoshida, S. Nagata, Transgenic expression of Fas in T cells blocks lymphoproliferation but not autoimmune disease in MRLIpr mice, J Immunol 160(8) (1998) 3805-11.

[51] J. Wu, T. Zhou, J. Zhang, J. He, W.C. Gause, J.D. Mountz, Correction of accelerated autoimmune disease by early replacement of the mutated Ipr gene with the normal Fas apoptosis gene in the T cells of transgenic MRL-Ipr/Ipr mice, Proc Natl Acad Sci U S A 91(6) (1994) 2344-8.

[52] I. Mabrouk, S. Buart, M. Hasmim, C. Michiels, E. Connault, P. Opolon, G. Chiocchia, M. Levi-Strauss, S. Chouaib, S. Karray, Prevention of autoimmunity and control of recall response to exogenous antigen by Fas death receptor ligand expression on T cells, Immunity 29(6) (2008) 922-33.

[53] C.A. Klebanoff, C.D. Scott, A.J. Leonardi, T.N. Yamamoto, A.C. Cruz, C. Ouyang, M. Ramaswamy, R. Roychoudhuri, Y. Ji, R.L. Eil, M. Sukumar, J.G. Crompton, D.C. Palmer, Z.A. Borman, D. Clever, S.K. Thomas, S. Patel, Z. Yu, P. Muranski, H. Liu, E. Wang, F.M. Marincola, A. Gros, L. Gattinoni, S.A. Rosenberg, R.M. Siegel, N.P. Restifo, Memory T cell-driven differentiation of naive cells impairs adoptive immunotherapy, J Clin Invest 126(1) (2016) 31834.

[54] M.J. Berridge, P. Lipp, M.D. Bootman, The versatility and universality of calcium signalling, Nat Rev Mol Cell Biol 1(1) (2000) 11-21.

[55] E. Carafoli, Calcium signaling: a tale for all seasons, Proc Natl Acad Sci U S A 99(3) (2002) 1115-22.

[56] G. Hajnoczky, G. Csordas, M. Madesh, P. Pacher, The machinery of local Ca2+ signalling between sarco-endoplasmic reticulum and mitochondria, J Physiol 529 Pt 1 (2000) 69-81.

[57] R. Rizzuto, T. Pozzan, Microdomains of intracellular Ca2+: molecular determinants and functional consequences, Physiol Rev 86(1) (2006) 369-408.

[58] A.J. Morgan, F.M. Platt, E. Lloyd-Evans, A. Galione, Molecular mechanisms of endolysosomal Ca2+ signalling in health and disease, Biochem J 439(3) (2011) 349-74.

[59] P. Pizzo, V. Lissandron, P. Capitanio, T. Pozzan, $\mathrm{Ca}(2+)$ signalling in the Golgi apparatus, Cell Calcium 50(2) (2011) 184-92.

[60] A. Raffaello, C. Mammucari, G. Gherardi, R. Rizzuto, Calcium at the Center of Cell Signaling: Interplay between Endoplasmic Reticulum, Mitochondria, and Lysosomes, Trends Biochem Sci 41(12) (2016) 1035-1049. 
[61] P. Kischel, A. Girault, L. Rodat-Despoix, M. Chamlali, S. Radoslavova, H. Abou Daya, T. Lefebvre, A. Foulon, P. Rybarczyk, F. Hague, I. Dhennin-Duthille, M. Gautier, H. OuadidAhidouch, Ion Channels: New Actors Playing in Chemotherapeutic Resistance, Cancers (Basel) 11(3) (2019).

[62] D. Hanahan, R.A. Weinberg, Hallmarks of cancer: the next generation, Cell 144(5) (2011) 646-74.

[63] H. Lu, I. Chen, L.A. Shimoda, Y. Park, C. Zhang, L. Tran, H. Zhang, G.L. Semenza, Chemotherapy-Induced $\mathrm{Ca}(2+)$ Release Stimulates Breast Cancer Stem Cell Enrichment, Cell reports 18(8) (2017) 1946-1957.

[64] P. Rovere, E. Clementi, M. Ferrarini, S. Heltai, C. Sciorati, M.G. Sabbadini, C. Rugarli, A.A. Manfredi, CD95 engagement releases calcium from intracellular stores of long term activated, apoptosis-prone gammadelta T cells, J Immunol 156(12) (1996) 4631-7.

[65] J. Urresti, M. Ruiz-Meana, E. Coccia, J.C. Arevalo, J. Castellano, C. Fernandez-Sanz, K.M. Galenkamp, L. Planells-Ferrer, R.S. Moubarak, N. Llecha-Cano, S. Reix, D. Garcia-Dorado, B. Barneda-Zahonero, J.X. Comella, Lifeguard Inhibits Fas Ligand-mediated Endoplasmic Reticulum-Calcium Release Mandatory for Apoptosis in Type II Apoptotic Cells, J Biol Chem 291(3) (2016) 1221-34.

[66] A.L. Wozniak, X. Wang, E.S. Stieren, S.G. Scarbrough, C.J. Elferink, D. Boehning, Requirement of biphasic calcium release from the endoplasmic reticulum for Fas-mediated apoptosis, J Cell Biol 175(5) (2006) 709-14.

[67] Y.F. Chen, Y.T. Chen, W.T. Chiu, M.R. Shen, Remodeling of calcium signaling in tumor progression, J Biomed Sci 20 (2013) 23.

[68] M.P. Stemmler, R.L. Eccles, S. Brabletz, T. Brabletz, Non-redundant functions of EMT transcription factors, Nat Cell Biol 21(1) (2019) 102-112.

[69] K.R. Fischer, A. Durrans, S. Lee, J. Sheng, F. Li, S.T. Wong, H. Choi, T. El Rayes, S. Ryu, J. Troeger, R.F. Schwabe, L.T. Vahdat, N.K. Altorki, V. Mittal, D. Gao, Epithelial-to-mesenchymal transition is not required for lung metastasis but contributes to chemoresistance, Nature 527(7579) (2015) 472-6.

[70] M.L. Gardel, I.C. Schneider, Y. Aratyn-Schaus, C.M. Waterman, Mechanical integration of actin and adhesion dynamics in cell migration, Annu Rev Cell Dev Biol 26 (2010) 315-33.

[71] J.T. Parsons, A.R. Horwitz, M.A. Schwartz, Cell adhesion: integrating cytoskeletal dynamics and cellular tension, Nat Rev Mol Cell Biol 11(9) (2010) 633-43.

[72] N. Prevarskaya, R. Skryma, Y. Shuba, Calcium in tumour metastasis: new roles for known actors, Nat Rev Cancer 11(8) (2011) 609-18.

[73] A.J. Ridley, M.A. Schwartz, K. Burridge, R.A. Firtel, M.H. Ginsberg, G. Borisy, J.T. Parsons, A.R. Horwitz, Cell migration: integrating signals from front to back, Science 302(5651) (2003) 1704-9.

[74] M. Monet, M. Poet, S. Tauzin, A. Fouque, A. Cophignon, D. Lagadic-Gossmann, P. Vacher, P. Legembre, L. Counillon, The cleaved FAS ligand activates the $\mathrm{Na}(+) / \mathrm{H}(+)$ exchanger NHE1 through Akt/ROCK1 to stimulate cell motility, Scientific reports 6 (2016) 28008.

[75] F.C. Tsai, G.H. Kuo, S.W. Chang, P.J. Tsai, Ca2+ signaling in cytoskeletal reorganization, cell migration, and cancer metastasis, Biomed Res Int 2015 (2015) 409245.

[76] A. Bhatt, I. Kaverina, C. Otey, A. Huttenlocher, Regulation of focal complex composition and disassembly by the calcium-dependent protease calpain, J Cell Sci 115(Pt 17) (2002) 341525.

[77] C. Wei, X. Wang, M. Zheng, H. Cheng, Calcium gradients underlying cell migration, Curr Opin Cell Biol 24(2) (2012) 254-61. 
[78] F.C. Tsai, A. Seki, H.W. Yang, A. Hayer, S. Carrasco, S. Malmersjo, T. Meyer, A polarized $\mathrm{Ca} 2+$, diacylglycerol and STIM1 signalling system regulates directed cell migration, Nat Cell Biol 16(2) (2014) 133-44.

[79] F.C. Tsai, T. Meyer, Ca2+ pulses control local cycles of lamellipodia retraction and adhesion along the front of migrating cells, Curr Biol 22(9) (2012) 837-42.

[80] J. Lee, A. Ishihara, G. Oxford, B. Johnson, K. Jacobson, Regulation of cell movement is mediated by stretch-activated calcium channels, Nature 400(6742) (1999) 382-6.

[81] S. Tang, X. Wang, Q. Shen, X. Yang, C. Yu, C. Cai, G. Cai, X. Meng, F. Zou, Mitochondrial $\mathrm{Ca}(2)(+)$ uniporter is critical for store-operated $\mathrm{Ca}(2)(+)$ entry-dependent breast cancer cell migration, Biochem Biophys Res Commun 458(1) (2015) 186-93.

[82] S. Linder, C. Wiesner, M. Himmel, Degrading devices: invadosomes in proteolytic cell invasion, Annu Rev Cell Dev Biol 27 (2011) 185-211.

[83] D.A. Murphy, S.A. Courtneidge, The 'ins' and 'outs' of podosomes and invadopodia: characteristics, formation and function, Nat Rev Mol Cell Biol 12(7) (2011) 413-26.

[84] C.C. Mader, M. Oser, M.A. Magalhaes, J.J. Bravo-Cordero, J. Condeelis, A.J. Koleske, H. Gil-Henn, An EGFR-Src-Arg-cortactin pathway mediates functional maturation of invadopodia and breast cancer cell invasion, Cancer Res 71(5) (2011) 1730-41.

[85] Y.R. Pan, C.L. Chen, H.C. Chen, FAK is required for the assembly of podosome rosettes, J Cell Biol 195(1) (2011) 113-29.

[86] H. Yamaguchi, S. Yoshida, E. Muroi, N. Yoshida, M. Kawamura, Z. Kouchi, Y. Nakamura, R. Sakai, K. Fukami, Phosphoinositide 3-kinase signaling pathway mediated by p110alpha regulates invadopodia formation, J Cell Biol 193(7) (2011) 1275-88.

[87] Y. Kato, S. Ozawa, M. Tsukuda, E. Kubota, K. Miyazaki, Y. St-Pierre, R. Hata, Acidic extracellular $\mathrm{pH}$ increases calcium influx-triggered phospholipase $\mathrm{D}$ activity along with acidic sphingomyelinase activation to induce matrix metalloproteinase-9 expression in mouse metastatic melanoma, FEBS J 274(12) (2007) 3171-83.

[88] M. Monet, D. Gkika, V. Lehen'kyi, A. Pourtier, F. Vanden Abeele, G. Bidaux, V. Juvin, F. Rassendren, S. Humez, N. Prevarsakaya, Lysophospholipids stimulate prostate cancer cell migration via TRPV2 channel activation, Biochim Biophys Acta 1793(3) (2009) 528-39.

[89] Y. Okamoto, T. Ohkubo, T. Ikebe, J. Yamazaki, Blockade of TRPM8 activity reduces the invasion potential of oral squamous carcinoma cell lines, Int J Oncol 40(5) (2012) 1431-40.

[90] G. Busco, R.A. Cardone, M.R. Greco, A. Bellizzi, M. Colella, E. Antelmi, M.T. Mancini, M.E. Dell'Aquila, V. Casavola, A. Paradiso, S.J. Reshkin, NHE1 promotes invadopodial ECM proteolysis through acidification of the peri-invadopodial space, FASEB J 24(10) (2010) 390315.

[91] B.T. Beaty, V.P. Sharma, J.J. Bravo-Cordero, M.A. Simpson, R.J. Eddy, A.J. Koleske, J. Condeelis, beta1 integrin regulates Arg to promote invadopodial maturation and matrix degradation, Mol Biol Cell 24(11) (2013) 1661-75, S1-11.

[92] M. Le Gallo, A. Poissonnier, P. Blanco, P. Legembre, CD95/Fas, Non-Apoptotic Signaling Pathways, and Kinases, Frontiers in immunology 8 (2017) 1216.

[93] A. Fouque, E. Lepvrier, L. Debure, Y. Gouriou, M. Malleter, V. Delcroix, M. Ovize, T. Ducret, C. Li, M. Hammadi, P. Vacher, P. Legembre, The apoptotic members CD95, BclxL, and Bcl-2 cooperate to promote cell migration by inducing $\mathrm{Ca}(2+)$ flux from the endoplasmic reticulum to mitochondria, Cell Death Differ 23(10) (2016) 1702-16.

[94] T.S. Soderstrom, S.D. Nyberg, J.E. Eriksson, CD95 capping is ROCK-dependent and dispensable for apoptosis, J Cell Sci 118(Pt 10) (2005) 2211-23. 
[95] S. Latour, I. Mahouche, F. Cherrier, L. Azzi-Martin, V. Velasco, P. Soubeyran, J.P. Merlio, S. Poglio, L. Bresson-Bepoldin, Calcium Independent Effect of Orai1 and STIM1 in Non-Hodgkin B Cell Lymphoma Dissemination, Cancers (Basel) 10(11) (2018).

[96] A.V. Shinde, R.K. Motiani, X. Zhang, I.F. Abdullaev, A.P. Adam, J.C. Gonzalez-Cobos, W. Zhang, K. Matrougui, P.A. Vincent, M. Trebak, STIM1 controls endothelial barrier function independently of Orai1 and Ca2+ entry, Sci Signal 6(267) (2013) ra18.

[97] J.A. Stolwijk, X. Zhang, M. Gueguinou, W. Zhang, K. Matrougui, C. Renken, M. Trebak, Calcium Signaling Is Dispensable for Receptor Regulation of Endothelial Barrier Function, J Biol Chem 291(44) (2016) 22894-22912.

[98] C. Frantz, A. Karydis, P. Nalbant, K.M. Hahn, D.L. Barber, Positive feedback between Cdc42 activity and $\mathrm{H}+$ efflux by the $\mathrm{Na}-\mathrm{H}$ exchanger NHE1 for polarity of migrating cells, J Cell Biol 179(3) (2007) 403-10.

[99] L.K. Putney, S.P. Denker, D.L. Barber, The changing face of the $\mathrm{Na}+/ \mathrm{H}+$ exchanger, NHE1: structure, regulation, and cellular actions, Annu Rev Pharmacol Toxicol 42 (2002) 527-52.

[100] C. Frantz, G. Barreiro, L. Dominguez, X. Chen, R. Eddy, J. Condeelis, M.J. Kelly, M.P. Jacobson, D.L. Barber, Cofilin is a $\mathrm{pH}$ sensor for actin free barbed end formation: role of phosphoinositide binding, J Cell Biol 183(5) (2008) 865-79.

[101] N. Tania, J. Condeelis, L. Edelstein-Keshet, Modeling the synergy of cofilin and Arp2/3 in lamellipodial protrusive activity, Biophys J 105(9) (2013) 1946-55.

[102] M. Oser, H. Yamaguchi, C.C. Mader, J.J. Bravo-Cordero, M. Arias, X. Chen, V. Desmarais, J. van Rheenen, A.J. Koleske, J. Condeelis, Cortactin regulates cofilin and N-WASp activities to control the stages of invadopodium assembly and maturation, J Cell Biol 186(4) (2009) 57187.

[103] M.A. Magalhaes, D.R. Larson, C.C. Mader, J.J. Bravo-Cordero, H. Gil-Henn, M. Oser, X. Chen, A.J. Koleske, J. Condeelis, Cortactin phosphorylation regulates cell invasion through a pH-dependent pathway, J Cell Biol 195(5) (2011) 903-20.

[104] G. Mouneimne, L. Soon, V. DesMarais, M. Sidani, X. Song, S.C. Yip, M. Ghosh, R. Eddy, J.M. Backer, J. Condeelis, Phospholipase $C$ and cofilin are required for carcinoma cell directionality in response to EGF stimulation, J Cell Biol 166(5) (2004) 697-708.

[105] S. Parlato, A.M. Giammarioli, M. Logozzi, F. Lozupone, P. Matarrese, F. Luciani, M. Falchi, W. Malorni, S. Fais, CD95 (APO-1/Fas) linkage to the actin cytoskeleton through ezrin in human T lymphocytes: a novel regulatory mechanism of the CD95 apoptotic pathway, Embo J 19(19) (2000) 5123-34.

[106] E.J. Steller, L. Ritsma, D.A. Raats, F.J. Hoogwater, B.L. Emmink, K.M. Govaert, J. Laoukili, I.H. Rinkes, J. van Rheenen, O. Kranenburg, The death receptor CD95 activates the cofilin pathway to stimulate tumour cell invasion, EMBO Rep 12(9) (2011) 931-7.

[107] R. Reinehr, A. Sommerfeld, D. Haussinger, CD95 ligand is a proliferative and antiapoptotic signal in quiescent hepatic stellate cells, Gastroenterology 134(5) (2008) 1494506.

[108] G.T. Motz, S.P. Santoro, L.P. Wang, T. Garrabrant, R.R. Lastra, I.S. Hagemann, P. Lal, M.D. Feldman, F. Benencia, G. Coukos, Tumor endothelium FasL establishes a selective immune barrier promoting tolerance in tumors, Nat Med (2014).

[109] A. Poissonnier, J.P. Guegan, H.T. Nguyen, D. Best, N. Levoin, G. Kozlov, K. Gehring, R. Pineau, F. Jouan, L. Morere, S. Martin, M. Thomas, E. Lazaro, I. Douchet, T. Ducret, P. van de Weghe, P. Blanco, M. Jean, P. Vacher, P. Legembre, Disrupting the CD95-PLCgamma1 interaction prevents Th17-driven inflammation, Nat Chem Biol 14(12) (2018) 1079-1089. 
[110] L. Gao, G.S. Gulculer, L. Golbach, H. Block, A. Zarbock, A. Martin-Villalba, Endothelial cellderived CD95 ligand serves as a chemokine in induction of neutrophil slow rolling and adhesion, Elife 5 (2016).

[111] S. Ganesh, C.F. Sier, G. Griffioen, H.J. Vloedgraven, A. de Boer, K. Welvaart, C.J. van de Velde, J.H. van Krieken, J.H. Verheijen, C.B. Lamers, et al., Prognostic relevance of plasminogen activators and their inhibitors in colorectal cancer, Cancer Res 54(15) (1994) 4065-71.

[112] A. Jeanes, C.J. Gottardi, A.S. Yap, Cadherins and cancer: how does cadherin dysfunction promote tumor progression?, Oncogene 27(55) (2008) 6920-9.

[113] L. Gagnoux-Palacios, H. Awina, S. Audebert, A. Rossin, M. Mondin, F. Borgese, C. PlanasBotey, A. Mettouchi, J.P. Borg, A.O. Hueber, Cell polarity and adherens junction formation inhibit epithelial Fas cell death receptor signaling, J Cell Biol (2018).

[114] A. Algeciras-Schimnich, E.M. Pietras, B.C. Barnhart, P. Legembre, S. Vijayan, S.L. Holbeck, M.E. Peter, Two CD95 tumor classes with different sensitivities to antitumor drugs, Proc Natl Acad Sci U S A 100(20) (2003) 11445-50.

[115] C.M. Henry, S.J. Martin, Caspase-8 Acts in a Non-enzymatic Role as a Scaffold for Assembly of a Pro-inflammatory "FADDosome" Complex upon TRAIL Stimulation, Mol Cell 65(4) (2017) 715-729 e5.

[116] S.P. Cullen, C.M. Henry, C.J. Kearney, S.E. Logue, M. Feoktistova, G.A. Tynan, E.C. Lavelle, M. Leverkus, S.J. Martin, Fas/CD95-induced chemokines can serve as "find-me" signals for apoptotic cells, Mol Cell 49(6) (2013) 1034-48.

[117] S. Cursi, A. Rufini, V. Stagni, I. Condo, V. Matafora, A. Bachi, A.P. Bonifazi, L. Coppola, G. Superti-Furga, R. Testi, D. Barila, Src kinase phosphorylates Caspase-8 on Tyr380: a novel mechanism of apoptosis suppression, EMBO J 25(9) (2006) 1895-905.

[118] J. Senft, B. Helfer, S.M. Frisch, Caspase-8 interacts with the p85 subunit of phosphatidylinositol 3-kinase to regulate cell adhesion and motility, Cancer Res 67(24) (2007) 11505-9.

[119] I.R. Powley, M.A. Hughes, K. Cain, M. MacFarlane, Caspase-8 tyrosine-380 phosphorylation inhibits CD95 DISC function by preventing procaspase-8 maturation and cycling within the complex, Oncogene 35(43) (2016) 5629-5640.

[120] A. Trauzold, C. Roder, B. Sipos, K. Karsten, A. Arlt, P. Jiang, J.I. Martin-Subero, D. Siegmund, S. Muerkoster, L. Pagerols-Raluy, R. Siebert, H. Wajant, H. Kalthoff, CD95 and TRAF2 promote invasiveness of pancreatic cancer cells, FASEB J 19(6) (2005) 620-2.

[121] M.D. Brooks, M.L. Burness, M.S. Wicha, Therapeutic Implications of Cellular Heterogeneity and Plasticity in Breast Cancer, Cell Stem Cell 17(3) (2015) 260-71.

[122] P.C. Hermann, S.L. Huber, T. Herrler, A. Aicher, J.W. Ellwart, M. Guba, C.J. Bruns, C. Heeschen, Distinct populations of cancer stem cells determine tumor growth and metastatic activity in human pancreatic cancer, Cell Stem Cell 1(3) (2007) 313-23.

[123] R. Pang, W.L. Law, A.C. Chu, J.T. Poon, C.S. Lam, A.K. Chow, L. Ng, L.W. Cheung, X.R. Lan, H.Y. Lan, V.P. Tan, T.C. Yau, R.T. Poon, B.C. Wong, A subpopulation of CD26+ cancer stem cells with metastatic capacity in human colorectal cancer, Cell Stem Cell 6(6) (2010) 603-15.

[124] J.E. Visvader, G.J. Lindeman, Cancer stem cells: current status and evolving complexities, Cell Stem Cell 10(6) (2012) 717-728.

[125] I. Pastushenko, C. Blanpain, EMT Transition States during Tumor Progression and Metastasis, Trends Cell Biol 29(3) (2019) 212-226.

[126] I. Pastushenko, A. Brisebarre, A. Sifrim, M. Fioramonti, T. Revenco, S. Boumahdi, A. Van Keymeulen, D. Brown, V. Moers, S. Lemaire, S. De Clercq, E. Minguijon, C. Balsat, Y. Sokolow, C. Dubois, F. De Cock, S. Scozzaro, F. Sopena, A. Lanas, N. D'Haene, I. Salmon, J.C. Marine, T. 
Voet, P.A. Sotiropoulou, C. Blanpain, Identification of the tumour transition states occurring during EMT, Nature 556(7702) (2018) 463-468.

[127] S. Liu, Y. Cong, D. Wang, Y. Sun, L. Deng, Y. Liu, R. Martin-Trevino, L. Shang, S.P. McDermott, M.D. Landis, S. Hong, A. Adams, R. D'Angelo, C. Ginestier, E. Charafe-Jauffret, S.G. Clouthier, D. Birnbaum, S.T. Wong, M. Zhan, J.C. Chang, M.S. Wicha, Breast cancer stem cells transition between epithelial and mesenchymal states reflective of their normal counterparts, Stem Cell Reports 2(1) (2014) 78-91.

[128] M.A. Nieto, R.Y. Huang, R.A. Jackson, J.P. Thiery, Emt: 2016, Cell 166(1) (2016) 21-45. [129] S.A. Mani, W. Guo, M.J. Liao, E.N. Eaton, A. Ayyanan, A.Y. Zhou, M. Brooks, F. Reinhard, C.C. Zhang, M. Shipitsin, L.L. Campbell, K. Polyak, C. Brisken, J. Yang, R.A. Weinberg, The epithelial-mesenchymal transition generates cells with properties of stem cells, Cell 133(4) (2008) 704-15.

[130] A.P. Morel, M. Lievre, C. Thomas, G. Hinkal, S. Ansieau, A. Puisieux, Generation of breast cancer stem cells through epithelial-mesenchymal transition, PLoS One 3(8) (2008) e2888.

[131] X. Zheng, J.L. Carstens, J. Kim, M. Scheible, J. Kaye, H. Sugimoto, C.C. Wu, V.S. LeBleu, R. Kalluri, Epithelial-to-mesenchymal transition is dispensable for metastasis but induces chemoresistance in pancreatic cancer, Nature 527(7579) (2015) 525-530.

[132] E. Beerling, D. Seinstra, E. de Wit, L. Kester, D. van der Velden, C. Maynard, R. Schafer, P. van Diest, E. Voest, A. van Oudenaarden, N. Vrisekoop, J. van Rheenen, Plasticity between Epithelial and Mesenchymal States Unlinks EMT from Metastasis-Enhancing Stem Cell Capacity, Cell reports 14(10) (2016) 2281-8.

[133] S. Paget, The distribution of secondary growths in cancer of the breast. 1889, Cancer Metastasis Rev 8(2) (1989) 98-101.

[134] D.I. Gabrilovich, S. Ostrand-Rosenberg, V. Bronte, Coordinated regulation of myeloid cells by tumours, Nat Rev Immunol 12(4) (2012) 253-68.

[135] M. Ouzounova, E. Lee, R. Piranlioglu, A. El Andaloussi, R. Kolhe, M.F. Demirci, D. Marasco, I. Asm, A. Chadli, K.A. Hassan, M. Thangaraju, G. Zhou, A.S. Arbab, J.K. Cowell, H. Korkaya, Monocytic and granulocytic myeloid derived suppressor cells differentially regulate spatiotemporal tumour plasticity during metastatic cascade, Nature communications 8 (2017) 14979.

[136] Z. Castano, B.P. San Juan, A. Spiegel, A. Pant, M.J. DeCristo, T. Laszewski, J.M. Ubellacker, S.R. Janssen, A. Dongre, F. Reinhardt, A. Henderson, A.G. Del Rio, A.M. Gifford, Z.T. Herbert, J.N. Hutchinson, R.A. Weinberg, C.L. Chaffer, S.S. McAllister, IL-1beta inflammatory response driven by primary breast cancer prevents metastasis-initiating cell colonization, Nat Cell Biol 20(9) (2018) 1084-1097.

[137] S.K. Wculek, I. Malanchi, Neutrophils support lung colonization of metastasis-initiating breast cancer cells, Nature 528(7582) (2015) 413-7.

[138] S. Peyvandi, S. Buart, B. Samah, M. Vetizou, Y. Zhang, L. Durrieu, M. Polrot, S. Chouaib, K. Benihoud, F. Louache, S. Karray, Fas Ligand Deficiency Impairs Tumor Immunity by Promoting an Accumulation of Monocytic Myeloid-Derived Suppressor Cells, Cancer Res 75(20) (2015) 4292-301.

[139] J. Zhu, C.G. Powis de Tenbossche, S. Cane, D. Colau, N. van Baren, C. Lurquin, A.M. Schmitt-Verhulst, P. Liljestrom, C. Uyttenhove, B.J. Van den Eynde, Resistance to cancer immunotherapy mediated by apoptosis of tumor-infiltrating lymphocytes, Nature communications 8(1) (2017) 1404. 
[140] P. Ceppi, A. Hadji, F.J. Kohlhapp, A. Pattanayak, A. Hau, X. Liu, H. Liu, A.E. Murmann, M.E. Peter, CD95 and CD95L promote and protect cancer stem cells, Nature communications 5 (2014) 5238.

[141] T. Ducret, C. Vandebrouck, M.L. Cao, J. Lebacq, P. Gailly, Functional role of storeoperated and stretch-activated channels in murine adult skeletal muscle fibres, J Physiol 575(Pt 3) (2006) 913-24.

[142] Y.W. Huang, S.J. Chang, H.I. Harn, H.T. Huang, H.H. Lin, M.R. Shen, M.J. Tang, W.T. Chiu, Mechanosensitive store-operated calcium entry regulates the formation of cell polarity, J Cell Physiol 230(9) (2015) 2086-97.

[143] I. Jardin, J.J. Lopez, G.M. Salido, J.A. Rosado, Store-Operated Ca(2+) Entry in Breast Cancer Cells: Remodeling and Functional Role, International journal of molecular sciences 19(12) (2018).

[144] R.A. Black, C.T. Rauch, C.J. Kozlosky, J.J. Peschon, J.L. Slack, M.F. Wolfson, B.J. Castner, K.L. Stocking, P. Reddy, S. Srinivasan, N. Nelson, N. Boiani, K.A. Schooley, M. Gerhart, R. Davis, J.N. Fitzner, R.S. Johnson, R.J. Paxton, C.J. March, D.P. Cerretti, A metalloproteinase disintegrin that releases tumour-necrosis factor-alpha from cells, Nature 385(6618) (1997) 729-33.

[145] M.L. Moss, S.L. Jin, M.E. Milla, D.M. Bickett, W. Burkhart, H.L. Carter, W.J. Chen, W.C. Clay, J.R. Didsbury, D. Hassler, C.R. Hoffman, T.A. Kost, M.H. Lambert, M.A. Leesnitzer, P. McCauley, G. McGeehan, J. Mitchell, M. Moyer, G. Pahel, W. Rocque, L.K. Overton, F. Schoenen, T. Seaton, J.L. Su, J.D. Becherer, et al., Cloning of a disintegrin metalloproteinase that processes precursor tumour-necrosis factor-alpha, Nature 385(6618) (1997) 733-6.

[146] E. Batlle, H. Clevers, Cancer stem cells revisited, Nat Med 23(10) (2017) 1124-1134. 


\section{Figure legends}

Figure 1. CD95 and CD95L structures. The death receptor CD95 encompasses three aminoterminal cysteine-rich domains (CRDs) and is expressed at the plasma membrane as a homotrimer through homotypic interactions occurring via its Pre-Ligand Assembly Domain. Binding of its cognate ligand CD95L induces receptor oligomerization and triggers proapoptotic signals through its death domain (DD). CD95 also implements an anti-apoptotic $\mathrm{Ca}^{2+}$ response through its calcium-inducing domain (CID). CD95L is a type II transmembrane protein harboring a unique proline-rich domain (PRD) for the recruitment of SH3 and WW domain-containing proteins. Membrane-bound CD95L (m-CD95L) binds to CD95 through cell-cell contact and induces cell death. Certain metalloproteases can release a soluble and noncytotoxic CD95L designated s-CD95L for soluble CD95L. The self-assembly domain (SA) is required for trimerization of the ligand. Plasmin can cleave CD95L, releasing a soluble and cytotoxic ligand. The TNF homology domain (THD) region of CD95L is responsible for CD95 binding.

Figure 2. s-CD95 and m-CD95L trigger different CD95-mediated signaling pathways. A. Interaction of transmembrane CD95L (m-CD95L) with CD95 favors the recruitment of FADD to the death domain (DD) of CD95. FADD binds procaspase-8 and FADD-like IL-1 $\beta$ converting enzyme-inhibitory protein (cFLIP) to form the Death-Inducing Signaling Complex (DISC). Oligomerization of procaspase- 8 promotes its autocatalytic activation and the release of a mature tetramer to the cytosol, which implements the apoptotic response. B. Stimulation of CD95 by soluble CD95L (s-CD95L) induces the recruitment of the PLC $\gamma 1$ to the CD95 Calcium-Inducing Domain (CID). The phospholipase generates inositol triphosphate $\left(\mathrm{InsP}_{3}\right)$ by hydrolyzing phosphoinositol bisphosphate $\left(\mathrm{PIP}_{2}\right)$. $\operatorname{InsP}_{3}$ activates $\mathrm{IP}_{3}-\mathrm{R}$ present at the membrane of the endoplasmic reticulum (ER) releasing $\mathrm{Ca}^{2+}$. This calcium response is 
enhanced through the activation of the ORAI1 channel. The increased concentration of $\mathrm{Ca}^{2+}$ underneath the plasma membrane activates PKC- $\beta 2$, which interferes with the recruitment of FADD to the DISC. In the MISC, NADPH oxidase 3 (NOX3) is also recruited and produces reactive oxygen species (ROS), which activate c-Yes. This Src kinase can recruit receptor tyrosine kinases and phosphorylate different proteins localized in the MISC that are responsible for PI3K/Akt signaling pathway activation and cell migration.

Figure 3. Spatial and temporal regulation of intracellular $\mathrm{Ca}^{2+}$ concentration control cell migration. In the front, CD95 engagement induces the activation of phospholipase C $\gamma$ (PLC $\gamma$ ), leading to the activation of inositol triphosphate (IP3) receptors and the depletion of calcium from the endoplasmic reticulum (ER). This in turn stimulates the calcium sensor STIM1, which transactivates the ORAI1 channel and induces store-operated calcium (SOC) entry. This localized SOC entry promotes the autophosphorylation of Focal Adhesion Kinase $\left(\mathrm{FAK}^{397}\right)$ via activation of calcium-dependent $\mathrm{PKC}_{\beta}$ in the front and the degradation of $(\mathrm{FAK})$ in the rear by the calcium-dependent $\mu$-calpain protease, enhancing focal adhesion (FA) turnover and polarized cell motility. In the rear, local $\mathrm{Ca}^{2+}$ pulses activate Rho-associated protein kinase (ROCK) and myosin light chain kinase (MLCK), which phosphorylates myosin II for proper actin treadmilling and recycling. In the front, the Pyk2/rac1 pair regulates cytoskeleton organization via a calcium-dependent mechanism. DAG: diacylglycerol; PMCA: plasma membrane $\mathrm{Ca}^{2+}$-ATPase.

Figure 4. Model for steering a migrating cell. During migration, cells exhibit a typical rearto-front polarization. A $\left[\mathrm{Ca}^{2+}\right]$ gradient is observed in the polarized cell by which high $\left[\mathrm{Ca}^{2+}\right]$ at the back and low $\left[\mathrm{Ca}^{2+}\right]$ at the leading edge facilitate the formation of functional local $\mathrm{Ca}^{2+}$ pulses. This $\left[\mathrm{Ca}^{2+}\right]$ gradient is ensured by the accumulation of the plasma membrane $\mathrm{Ca}^{2+}$ 
ATPase (PMCA) pump and intracellular $\mathrm{Ca}^{2+}$ compartments (ER, mitochondria) at the cell leading edge, which mediate $\mathrm{Ca}^{2+}$ extrusion and pumping, respectively. Intracellular $\mathrm{Ca}^{2+}$ entry controlled by a CD95-induced ORAI1-dependent mechanism establishes local $\mathrm{Ca}^{2+}$ flickers/pulses at the leading edge. Stretch-activated channels (TRPM7 and TRPV) are involved in the polarized calcium influx in migrating cells. CD95-stimulated NHE1 activity increases intracellular $\mathrm{pH}$ and promotes actin polymerization through a cofilin-dependent mechanism. Cdc42, a small $\mathrm{pH}$-dependent Rho-GTPase, regulates actin polymerization by binding to the neural Wiskott-Aldrich syndrome protein (N-WASP), which activates the Arp2/3 complex. $\mathrm{H}^{+}$ extruded by NHE1 causes extracellular acidification, which promotes the activity of matrix metalloproteinases (MMPs). $\mathrm{Ca}^{2+}$ influx through ORAI channels stimulates calpain to cleave cortactin. ERM: Ezrin Radixin Moesin, FA: Focal Adhesion. 


\section{CD95}

\section{CD95L c-term \\ FIGURE 1}
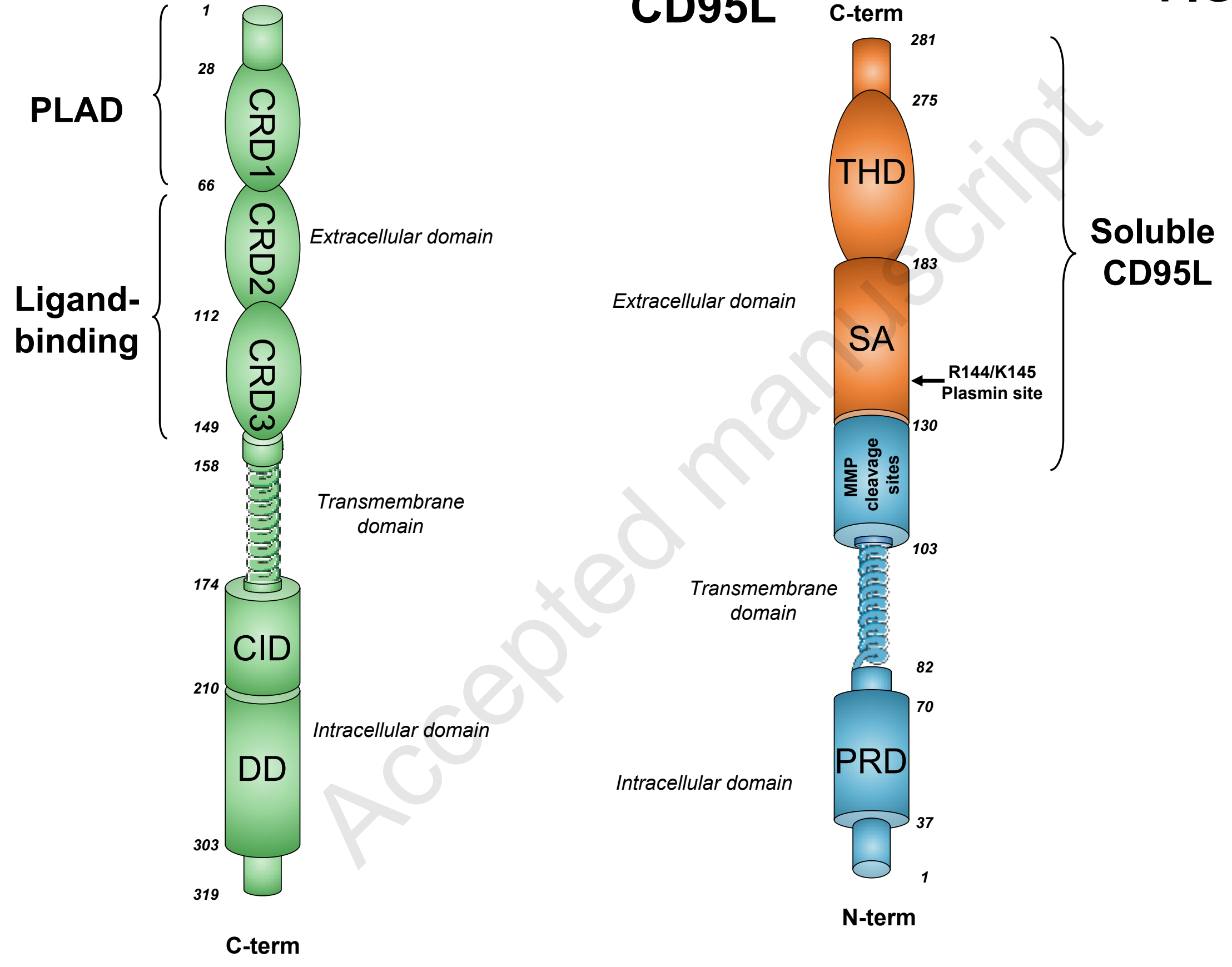


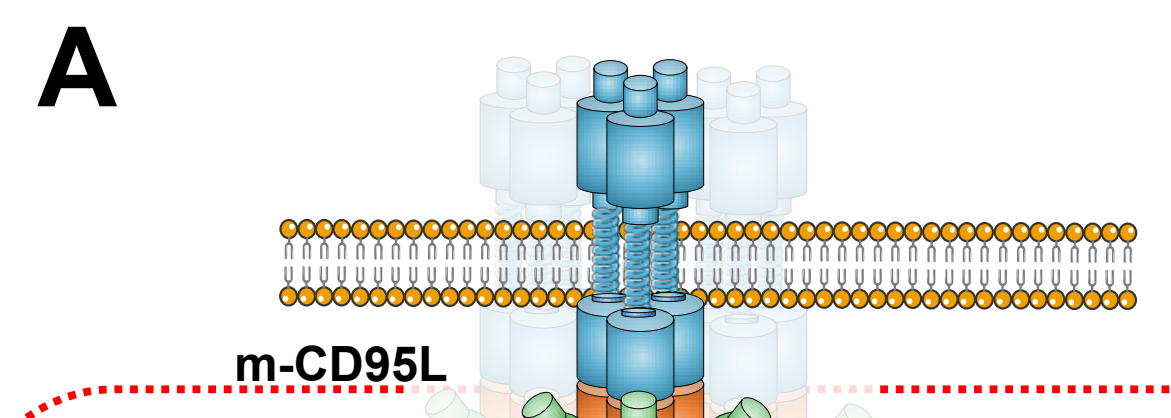

B
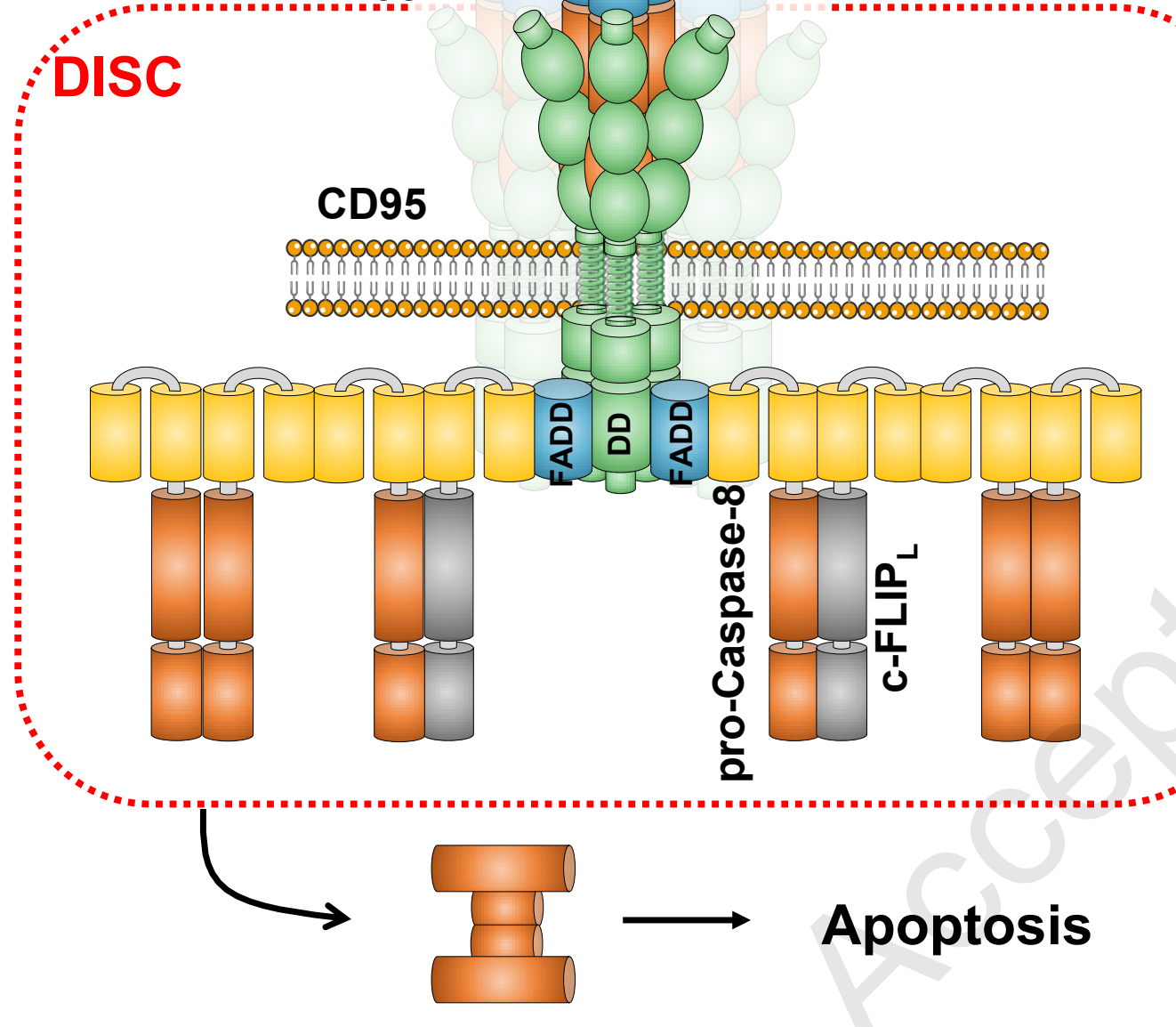

Caspase-8

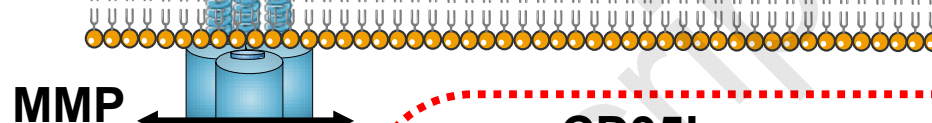

cleavage
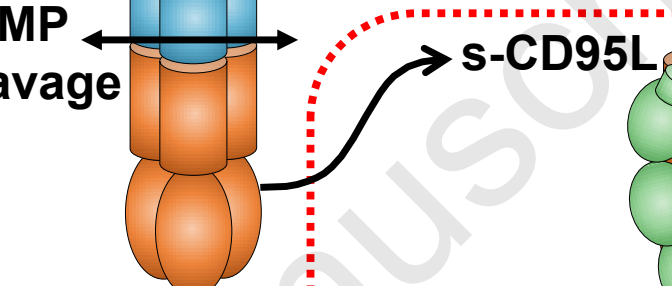

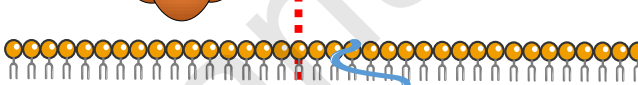
$\mathrm{Ca}^{2+} \mathrm{O}$

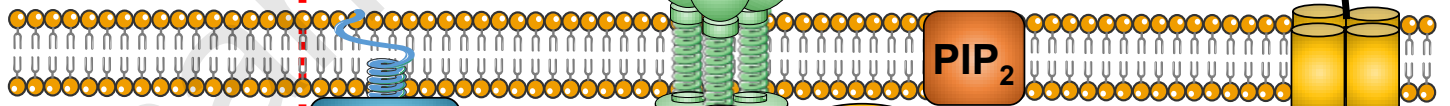

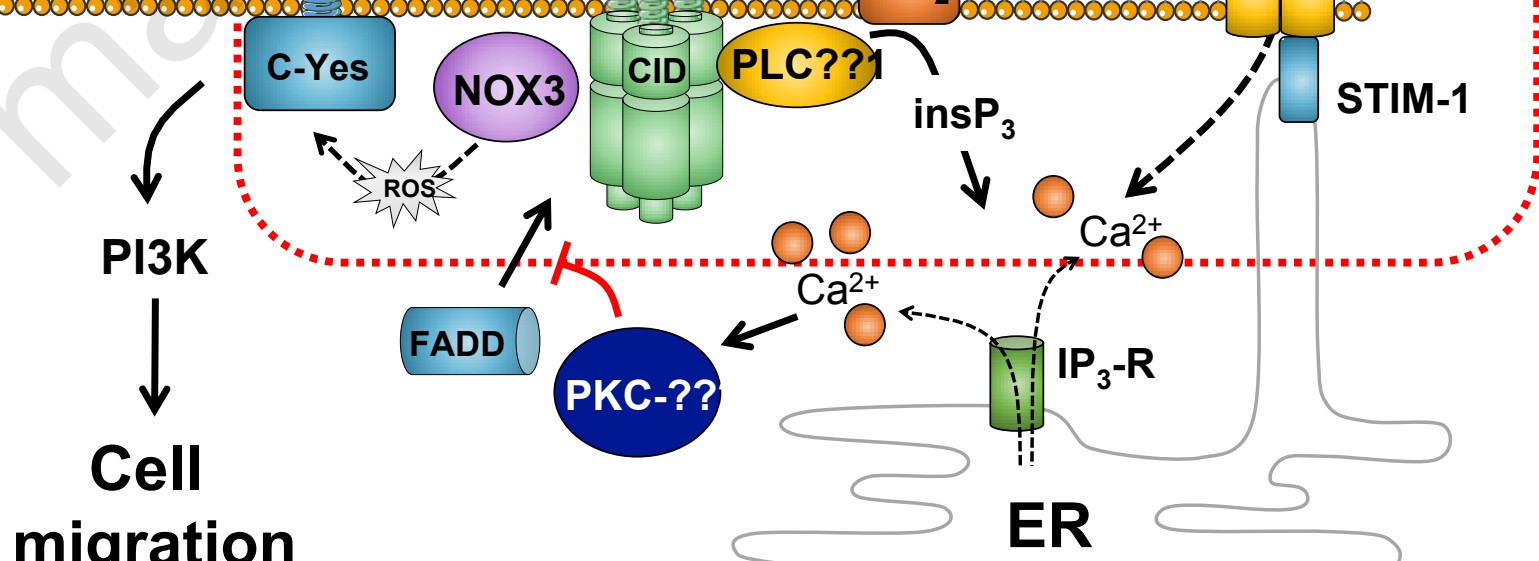
migration

ER 


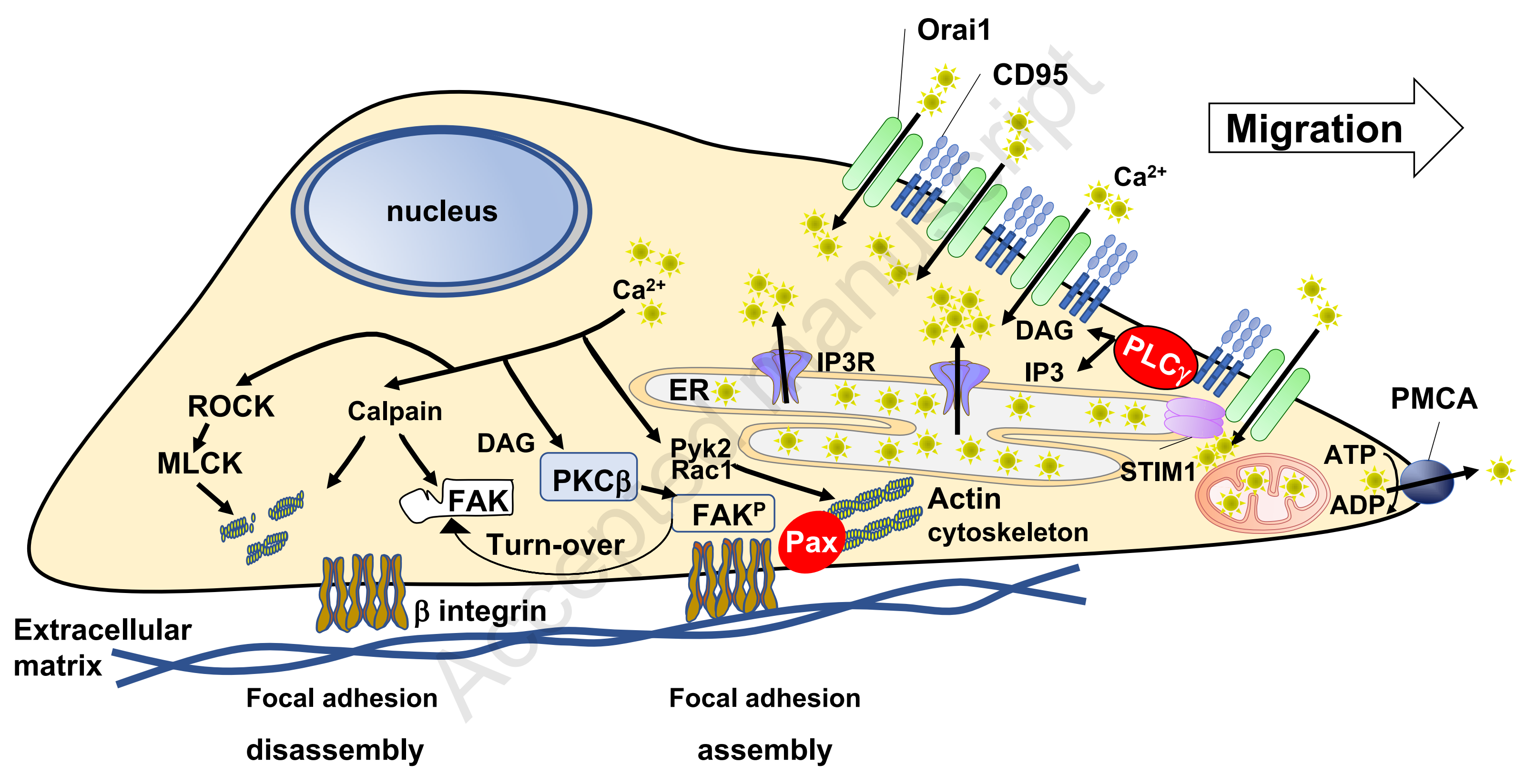




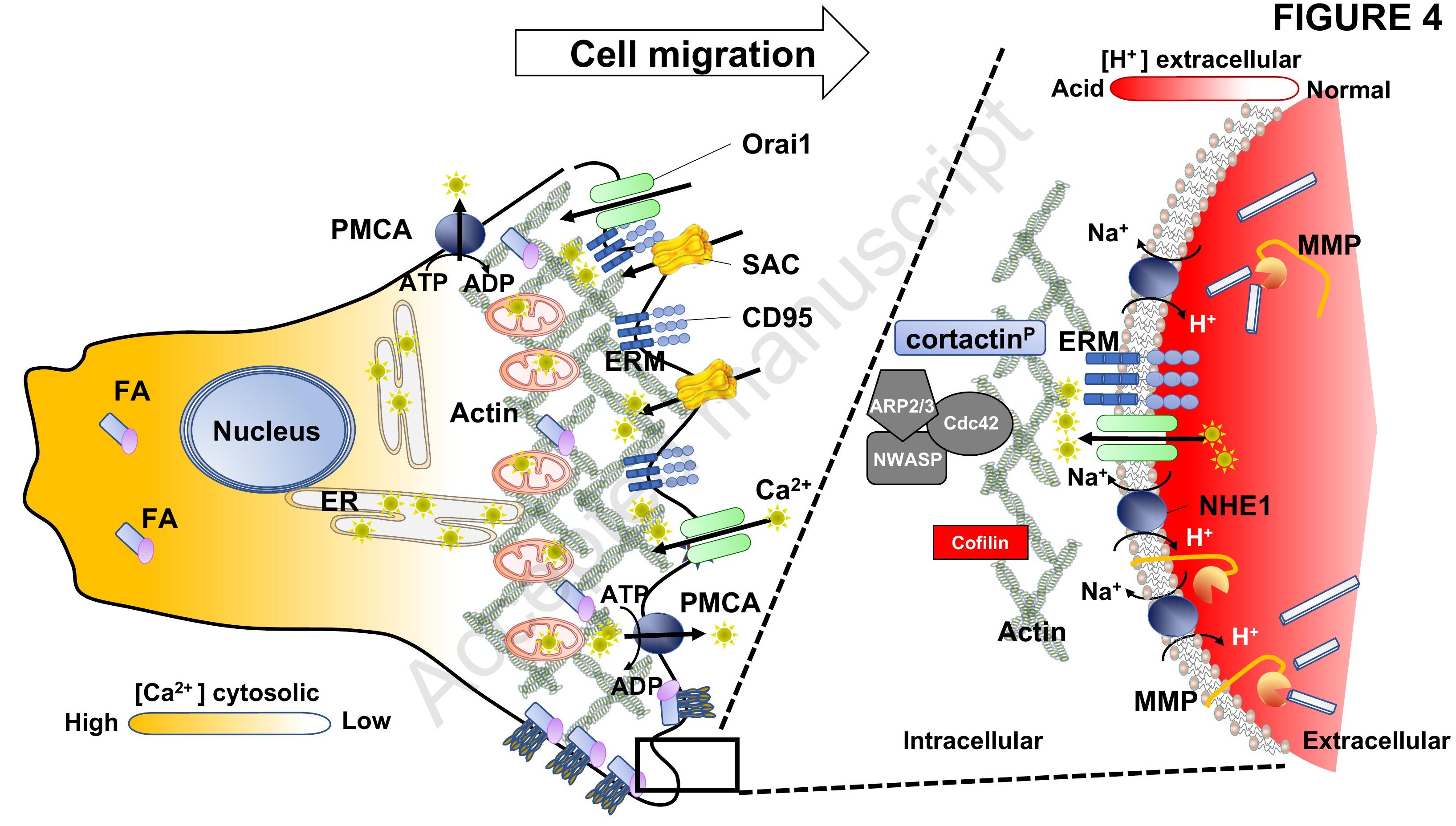

